The Free Internet Journal

for Organic Chemistry
Review

Arkivoc 2020, part i, 117-152

\title{
Recent advances in the synthesis of pyrroles via multicomponent reactions using arylglyoxals
}

\author{
Ramin Javahershenas, ${ }^{* a}$ Fatemeh Majidi Arlan, ${ }^{b}$ Rolf Herman Prager, ${ }^{c}$ and Jabbar Khalafy ${ }^{a}$ \\ ${ }^{a}$ Department of Organic Chemistry, Faculty of Chemistry, Urmia University, Urmia, Iran \\ ${ }^{b}$ Research Department of Analytical Chemistry, Iranian Academic Center for Education, \\ Culture and Research, P. O. Box 57155-397, Urmia, Iran \\ ${ }^{c}$ Faculty of Science \& Engineering, School of Chemical \& Physical Sciences, Flinders University, \\ Adelaide, S. Australia 5042, Australia
}

Email address: jshbco@yahoo.com

Received 02-07-2020

Accepted 03-29-2020

Published on line $05-04-2020$

\section{Abstract}

Pyrrole is widely known as an active pharmacophore. This core framework plays an important role in several natural and biological products. Due to its properties, developing such scaffolds has attracted much attention. The accessibility of these role-playing heterocyclic motifs via easy, high efficiency and developed methodologies is of interest and value in the creation of new heterocyclic compounds. This review highlights the broad range of applications of arylglyoxals in the synthesis of pyrrole derivatives via multicomponent reactions over the period 2010-2019.

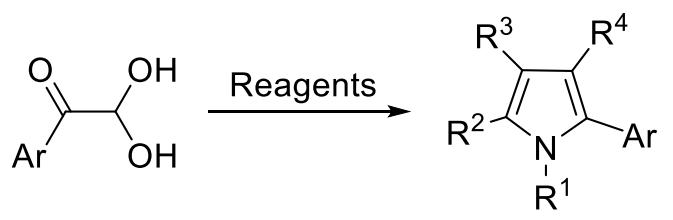

Keywords: Pyrroles, arylglyoxals, multicomponent reactions 


\section{Table of Contents}

1. Introduction

1.1 Pyrroles and their importance in biochemistry and medicine

1.2 Multicomponent and domino reactions

1.3 Arylglyoxals: their availability and utility

1.4 Application of active methylene containing compounds in pyrrole synthesis

2. Pyrrole Syntheses using Arylglyoxals via Multicomponent Reactions

2.1 Synthesis of monocyclic pyrroles

2.2 Synthesis of 1,5,6,7-dihydro-4H-indol-4-ones and other indoles

2.3 Synthesis of other fused pyrrole heterocycles

3. Conclusions

4. Acknowledgements

References

Authors' biographies

\section{Introduction}

\subsection{Pyrroles and their importance in biochemistry and medicine}

Pyrroles are five-membered nitrogen containing heterocycles, and have attracted much attention due to their presence in a wide range of natural and synthetic bioactive compounds. ${ }^{1-7}$ The pyrrole ring is a constituent of numerous natural compounds such as chlorophyll, the porphyrins of heme, vitamin B12, digestive fluid pigments like haematoidin and biliverdin, in bacteriochlorins and porphyrinogens. Porphyrins are a group of heterocyclic macromolecules that are synthesized by the cyclocondensation reaction between pyrrole and several aliphatic or aromatic aldehydes in the presence of various catalysts and under different conditions. Non naturally pyrroles have been found to possess considerable biological activities, and many drugs with this scaffold motif have been designed and synthesized. ${ }^{8-14}$ The important pharmaceutical, biological and materials science applications of pyrrole, and its significance as an intermediate in the synthesis of natural products, have led pyrroles to become an important class of heterocyclic compounds in organic chemistry. ${ }^{14-21}$

Therefore, due to the manifold pharmaceutical and biological properties of pyrrole derivatives, such as antibacterial, $^{22-26}$ anticancer $^{27-33}$ (for the treatment of several types of tumor), antifungal, ${ }^{34-37}$ antiinflammatory, ${ }^{38-40}$ antiviral, ${ }^{41,42}$ antimalarial, ${ }^{43}$ antiparasitic, ${ }^{44}$ anticholestaemic (Atorvastatin is a drug widely used as a cholesterol-lowering agent), ${ }^{45}$ antibiotic, ${ }^{46}$ anti-HIV, ${ }^{47-49}$ antioxidant, ${ }^{50-53}$ and as a systemic enzyme inhibitor, ${ }^{54,55}$ these compounds have been the subject of considerable research and development in the pharmaceutical industry (Figure 1). 
<smiles>[R]c1ccc(-c2csc(NC(=O)c3[nH]c(C)c(C(=O)Nc4nc(-c5ccc([R])cc5)cs4)c3C)n2)cc1</smiles>

Antibacterial<smiles>Cc1ccc(C(=O)c2ccc(CC(=O)O)n2C)cc1</smiles>

Antiinflammatory<smiles>O=[N+]([O-])c1c(Cl)cccc1-c1c[nH]cc1Cl</smiles>

Antifungal<smiles>Cc1ccc(C)n1-c1ccc(C(=O)O)c(O)c1</smiles>

Antiviral

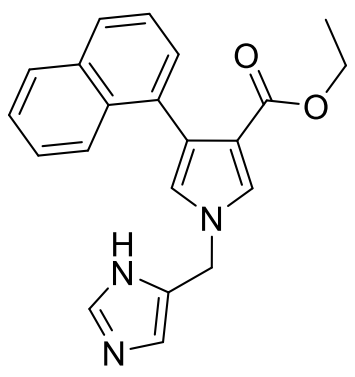

Anticancer
Antiparasitic<smiles>O=C(O)CC1CNC(=O)c2cc(Br)c(Br)n21</smiles><smiles>CC(C)c1c(CO)cn(Cc2ccncc2)c1Sc1cc(Cl)cc(Cl)c1</smiles>

Enzyme inhibitor<smiles>[R]Cc1nc2ccccc2c2cc[nH]c12</smiles>

Antimalarial<smiles>Cc1ccc(-c2c(-c3ccccc3)c(C(=O)Nc3ccccc3)c(C(C)C)n2CC[C@@H](O)C[C@@H](O)C(=O)O)cc1</smiles>

Anticholestaemic (Atorvastatin)

Figure 1. Some pyrrole-derived drugs.

\subsection{Multicomponent and domino reactions}

The design and synthesis of hetero-aromatic compounds via a simple, efficient and economical method, with the potential to form several bonds in a single operation, are important factors of a valuable and useful synthetic method. The last few years have seen an enormous increase in the number of applications of multicomponent reactions (MCRs) being reported. MCRs are a convenient route to architecturally complex heterocyclic compounds, ${ }^{56-62}$ and they are powerful synthetic tools for the synthesis of a wide variety of biologically active heterocyclic compounds, providing simple and rapid access to complex structures in a single synthetic operation.

Organic chemists are interested in multicomponent reactions involving domino processes in the synthesis of many organic molecules. The products of such reactions have attracted much attention in recent years due to the wide range of their potential biological and pharmaceutical activities. ${ }^{63-66}$ These methods have afforded the easy and convenient isolation of products in short reaction times, usually with high atom-economy, high selectivity, and often by environmentally friendly chemical processes without requiring elaborate purification by solvent and chromatographic methods, both in academic laboratories and industrial processes. These 
synthetic procedures have been found suitable for the construction of many new and biologically significant molecules in medicinal chemistry. ${ }^{67-69}$

\subsection{Arylglyoxals: their availability and utility}

Arylglyoxals are very valuable synthons in the field of heteroaromatic chemistry, owing to these molecules having two active functional groups, aldehyde and ketone, with different reactivities. Therefore, for $\mathrm{C}-\mathrm{C}$ and $\mathrm{C}-\mathrm{N}$ bond formation via [3+2] cyclization, they provide two electrophilically active sites $(\mathrm{C}-\mathrm{O}$ and $\mathrm{C}=\mathrm{O}$ bonds) as 1,2 -acceptors, which can be attacked by the electron-rich $\beta-\mathrm{C}$ atom and the nucleophilic $\mathrm{NH}$ group in $\beta$ enaminones. Various methods have been reported for the synthesis of arylglyoxals in the literature. The most common method is oxidation of aryl methyl ketones by $\mathrm{SeO}_{2}$. The various synthetic methods along with reaction conditions are summarized in Table $1^{70,71}$

Table 1. Methods for the synthesis of arylglyoxals

\begin{tabular}{|c|c|}
\hline Method & Conditions \\
\hline $\begin{array}{l}\text { Chlorination of aryl methyl } \\
\text { ketones }\end{array}$ & 1,3- $\mathrm{Cl}_{2}-5,5-\mathrm{Me}_{2}$-hydantoin, $\mathrm{Cu}(\mathrm{OTf})_{2}, \mathrm{CHCl}_{3}$, reflux, $5-8 \mathrm{~h}$ \\
\hline Oxidation of aryl acetylenes & $\begin{array}{c}\text { (HMPA)MoO }\left(\mathrm{O}_{2}\right), \mathrm{Hg}(\mathrm{OAC})_{2}, \mathrm{DCE}-\mathrm{MeOH}, 0^{\circ} \mathrm{C}, 15 \mathrm{~min} \\
\mathrm{NBS}, \text { dry DMSO, rt, } 20 \mathrm{~h} \\
(\mathrm{PhSe})_{2},\left(\mathrm{NH}_{4}\right)_{2} \mathrm{~S}_{2} \mathrm{O}_{8}, \text { water- } \mathrm{CH}_{3} \mathrm{CN}, 60^{\circ} \mathrm{C} \text {, then chromatography on } \\
\mathrm{SiO}_{2}, \mathrm{DCM}-\mathrm{ROH}(99 / 1)\end{array}$ \\
\hline $\begin{array}{l}\text { Oxidation of aryl methyl } \\
\text { ketones }\end{array}$ & $\begin{array}{c}\mathrm{SeO}_{2} \text {, dioxane-water, reflux } \\
\mathrm{H}_{2} \mathrm{SeO}_{3} \text {, dioxane-water, reflux, } 4 \mathrm{~h} \\
\mathrm{SeO}_{2}, \mathrm{EtOH}, 10 \% \mathrm{HNO}_{3}(\mathrm{aq}), 90{ }^{\circ} \mathrm{C}, 1 \mathrm{~h} \\
(\mathrm{PhSe})_{2},\left(\mathrm{NH}_{4}\right)_{2} \mathrm{~S}_{2} \mathrm{O}_{8}, \mathrm{MeOH} \text {, reflux, } 1-4 \mathrm{~h} \\
48 \% \mathrm{HBr}(\mathrm{aq}), \mathrm{DMSO}, 55^{\circ} \mathrm{C}, 0.5-24 \mathrm{~h}\end{array}$ \\
\hline Oxidation of $\alpha$-diazoketones & Dimethyldioxirane, acetone, $\mathrm{rt}$ \\
\hline $\begin{array}{l}\text { Reaction of methyl benzoates } \\
\text { with DMSO then oxidation }\end{array}$ & $\begin{array}{l}\text { (1) DMSO, t-BuOK/ t-BuOH, rt, } 4 \mathrm{~h} \text {, then } \mathrm{HCl} \text {, water, rt, } 30 \mathrm{~h} \\
\text { (2) } \mathrm{Cu}(\mathrm{OAC})_{2} \cdot \mathrm{H}_{2} \mathrm{O}, \mathrm{CHCl}_{3}, \mathrm{rt}, 1 \mathrm{~h}\end{array}$ \\
\hline $\begin{array}{l}\text { Oxidation of phenacyl } \\
\text { bromides }\end{array}$ & $\begin{array}{c}\mathrm{DMSO}, \mathrm{rt}, 9 \mathrm{~h} \\
\alpha \text {-picoline } \mathrm{N} \text {-oxide, } 0^{\circ} \mathrm{C} \text {, then } \mathrm{Na}_{2} \mathrm{CO}_{3} \text {, water } \\
\mathrm{Et}_{2} \mathrm{NOH}, \mathrm{MeOH} \text {, reflux, } 2 \mathrm{~h}\end{array}$ \\
\hline $\begin{array}{l}\text { Reaction of organolithium } \\
\text { compounds with } \\
\text { diethoxyacetylpiperidine }\end{array}$ & $\begin{array}{l}\text { piperidine-1-yl-COCH(OEt) })_{2}, p-\mathrm{Me}_{2} \mathrm{NC}_{6} \mathrm{H}_{4} \mathrm{Li} \text {, ether, reflux, } 2 \mathrm{~h} \text {, then } \mathrm{HCl} \text {, } \\
\text { water, } \mathrm{N}_{2} \text { (atm.), rt, } 41 \mathrm{~h}\end{array}$ \\
\hline $\begin{array}{l}\text { Decomposition of phenacyl } \\
\text { nitrate esters }\end{array}$ & $\mathrm{NaOAc} .3 \mathrm{H}_{2} \mathrm{O}$, DMSO, $20-25^{\circ} \mathrm{C}, 25-55 \mathrm{~min}$ \\
\hline
\end{tabular}

\subsection{Application of active methylene containing compounds in pyrrole synthesis}

There are many synthetic methods for the synthesis of pyrrole derivatives and in most of them compounds such as $\alpha$-diazoketones, $\alpha$-dicarbonyls, $\alpha$-hydroxyketones, nitroalkanes, nitroalkenes, isocyanides, 1,4dicarbonyls, and alkynes are used as adaptable precursors. An overview of the syntheses of pyrrole structures by typical cycloaddition methods and using wide range of methylene active compounds is provided in Figures 2 and 3 , respectively. ${ }^{72,73}$ 


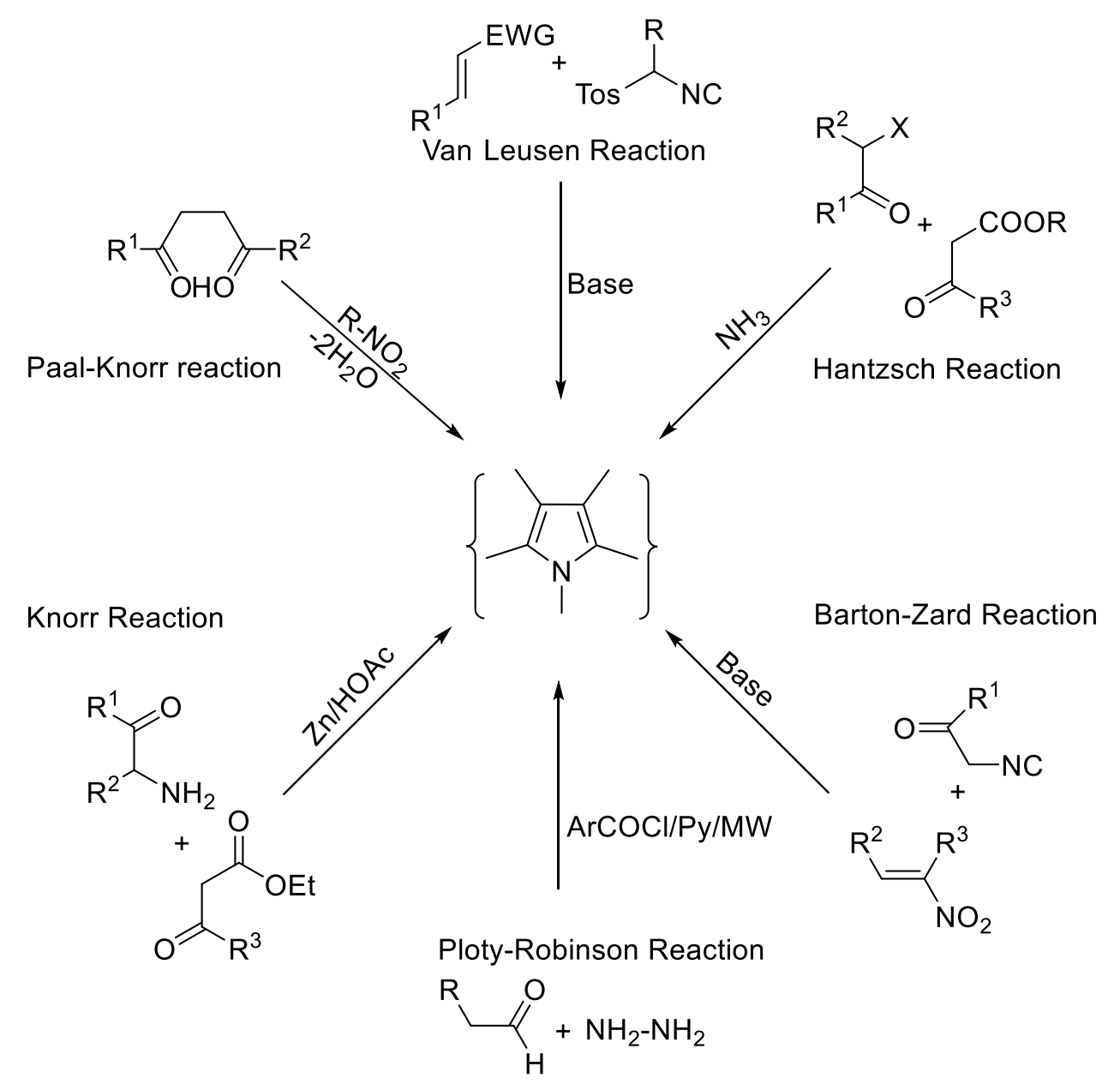

Figure 2. Typical cycloaddition methods for the synthesis of pyrroles. 


$$
\begin{aligned}
X= & \mathrm{CN}, \mathrm{COOH}, \mathrm{COOEt}, \mathrm{COOMe}, \mathrm{CONH}_{2}, \\
& \mathrm{CONHR}(\mathrm{R}=\mathrm{H}, \mathrm{Me}, \mathrm{Et}), \mathrm{SO}_{2} \mathrm{Ph}, 4-\mathrm{OMeC}_{6} \mathrm{H}_{4}
\end{aligned}
$$

$$
\mathrm{NC} \sim \mathrm{X}
$$<smiles>[R]C(=O)CC([R])=O</smiles>

$\mathrm{R}^{1}=\mathrm{R}^{2}=\mathrm{H}, \mathrm{Me}, \mathrm{Et}, \mathrm{n}-\mathrm{Pr}, \mathrm{O}-$ alkyl, O-allyl, t-Bu, $\mathrm{CH}_{2} \mathrm{OEt}$, CONHAr, $\mathrm{PO}(\mathrm{OMe})_{2}, \mathrm{Ph}$

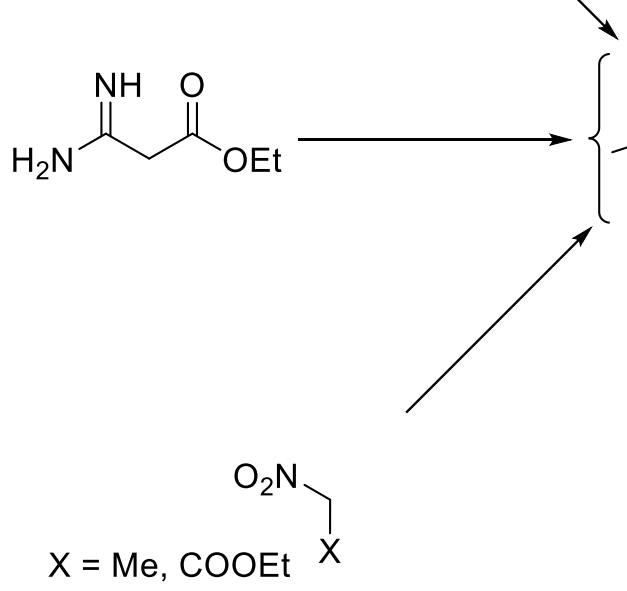<smiles>NCC(=O)CCl</smiles>

Figure 3. The syntheses of pyrroles using methylene active compounds

\section{Pyrrole Syntheses using Arylglyoxals via Multicomponent Reactions}

\subsection{Synthesis of monocyclic pyrroles}

The addition reaction of phosphines to electron-deficient carbon-carbon triple bonds is well known to produce a reactive zwitterionic intermediate, which can be trapped by various electrophiles. The reactions of adducts of dialkyl acetylenedicarboxylates with triphenylphosphine in the presence of a variety of organic acidic compounds, have been shown to trap the zwitterionic intermediates, to provide the synthesis of a series of carbocyclic and heterocyclic compounds through an efficient one-pot route. A four-component reaction leading to the substituted pyrroles 5 has been reported by Anaraki-Ardakani et al. with triphenylphosphine 1, a 2-aminopyridine 2, and dialkyl acetylenedicarboxylate $\mathbf{3}$ in the presence of arylglyoxals $\mathbf{4}$ at room temperature in dichloromethane, with good yields (Scheme 1$).^{74}$ 


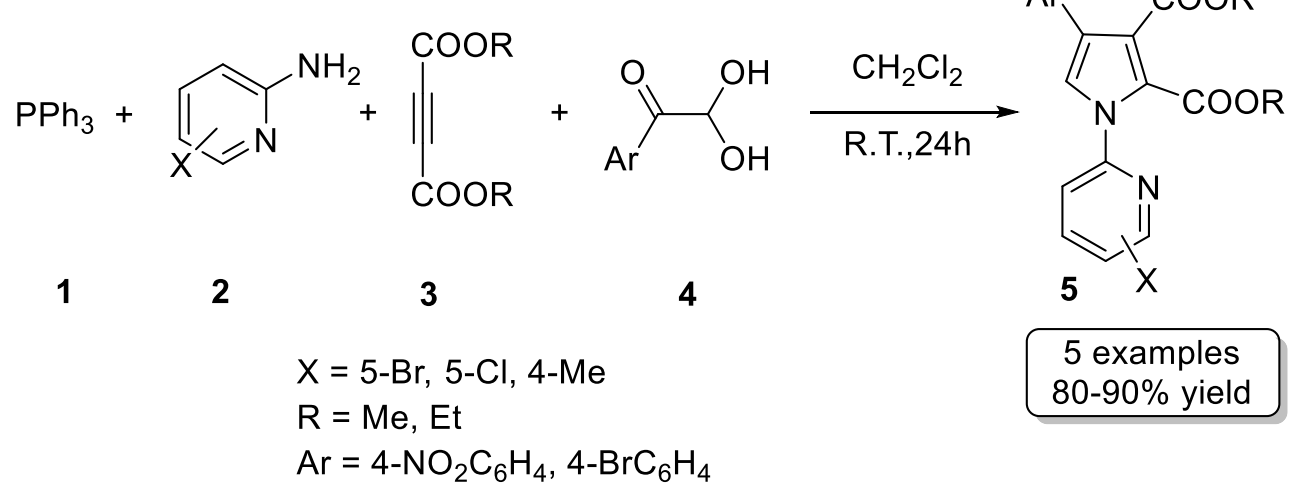

Scheme 1. One-pot synthesis of substituted pyrroles by Anaraki-Ardakani et al. ${ }^{74}$

In a recent environmentally benign and efficient contribution to these reactions, an iodine-promoted MCR protocol was described by Musawwer Khan and co-workers for the synthesis of two kinds of pyrrole. In a facile one-pot four-component reaction between dialkyl acetylenedicarboxylate 3, aromatic amines 8 and arylglyoxals 4 catalyzed by $10 \mathrm{~mol} \%$ of iodine in ethanol at room temperature, the 4-arylaminopyrrole-2,3dicarboxylate esters 9 were formed. Under the same reaction conditions, a three-component reaction between (E)-N-methyl-1-(methylthio)-2-nitroethenamine (NMSM, 7), aromatic amines 8 and arylglyoxals 4 provided the novel dihydro- $1 \mathrm{H}$-pyrrole derivatives 6 (Scheme 2$).^{75}$

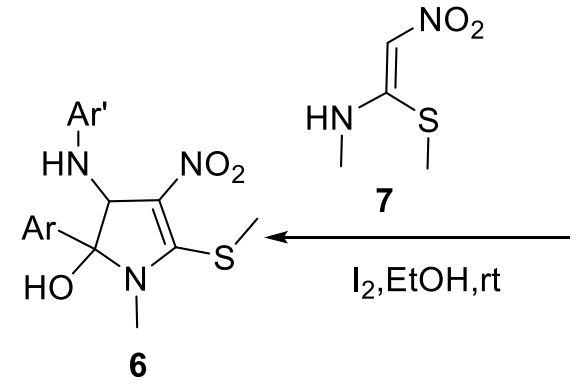

9 examples $80-87 \%$ yield

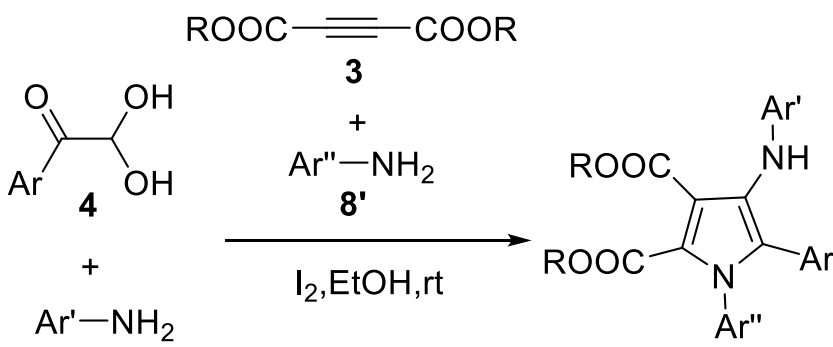

8

$\mathrm{Ar}=\mathrm{Ph}, 4-\mathrm{MeOC}_{6} \mathrm{H}_{4}$

$\mathrm{Ar}^{\prime}=\mathrm{Ph}, 4-\mathrm{MeC}_{6} \mathrm{H}_{4}, 4-\mathrm{ClC}_{6} \mathrm{H}_{4}, 4-\mathrm{BrC}_{6} \mathrm{H}_{4}, 4-\mathrm{EtC}_{6} \mathrm{H}_{4}$, 4-i- $\mathrm{PrC}_{6} \mathrm{H}_{4}, 4-\mathrm{FC}_{6} \mathrm{H}_{4}, 4-\mathrm{MeOC}_{6} \mathrm{H}_{4}, 4-\mathrm{NO}_{2} \mathrm{C}_{6} \mathrm{H}_{4}$, $3,4-(\mathrm{Me})_{2} \mathrm{C}_{6} \mathrm{H}_{3}$

Ar" = Ph, 4- $\mathrm{MeC}_{6} \mathrm{H}_{4}, 4-\mathrm{ClC}_{6} \mathrm{H}_{4}, 4-\mathrm{BrC}_{6} \mathrm{H}_{4}, 4-\mathrm{EtC}_{6} \mathrm{H}_{4}, 4-\mathrm{i}-\mathrm{PrC}_{6} \mathrm{H}_{4}, 4-\mathrm{FC}_{6} \mathrm{H}_{4}, 4-\mathrm{MeOC}_{6} \mathrm{H}_{4}$,

$\mathrm{R}=\mathrm{Et}$

Scheme 2. One-pot syntheses of substituted pyrroles developed by Musawwer Khan et al. ${ }^{75}$

Wang's group studied the four-component reaction between 1,3-dicarbonyl compounds 10, arylglyoxals 4, a dialkyl acetylenedicarboxylate $\mathbf{3}$ and aromatic amines $\mathbf{8}$ in ethanol as solvent under reflux and catalyst-free conditions; the reaction proceeded especially well, affording the expected products $\mathbf{1 1}$ in high yields (Scheme 3). ${ }^{76}$ 
<smiles>O=C1C=C(O)CCCCC1</smiles>

10<smiles>O=C([Al])C(O)O</smiles>

4<smiles>[R]OCC#CC(=O)O[R]</smiles>

3<smiles>[R]OC(=O)c1c(C2=C(O)CCCCCC2=O)c([Al])n([Al])c1C(=O)O[R]</smiles>

8

11

$$
\begin{aligned}
& \mathrm{R}=\mathrm{Me}, \mathrm{Et} \\
& \mathrm{Ar}=\mathrm{Ph}, 4-\mathrm{MeC}_{6} \mathrm{H}_{4}, 4-\mathrm{MeOC}_{6} \mathrm{H}_{4}, 4-\mathrm{ClC}_{6} \mathrm{H}_{4}, 4-\mathrm{BrC}_{6} \mathrm{H}_{4} \\
& \mathrm{Ar}^{\prime}=\mathrm{Ph}, 4-\mathrm{MeC}_{6} \mathrm{H}_{4}, 4-\mathrm{MeOC}_{6} \mathrm{H}_{4}, 4-\mathrm{ClC}_{6} \mathrm{H}_{4}, 4-\mathrm{BrC}_{6} \mathrm{H}_{4}, 4-\mathrm{FC}_{6} \mathrm{H}_{4}, \\
& \quad 4-\mathrm{NO}_{2} \mathrm{C}_{6} \mathrm{H}_{4}, 3-\mathrm{ClC}_{6} \mathrm{H}_{4}, 2-\mathrm{ClC}_{6} \mathrm{H}_{4}, n-\mathrm{Bu}_{6} \mathrm{C}_{6} \mathrm{H}_{4}, 3,5-\mathrm{Me}_{2} \mathrm{C}_{6} \mathrm{H}_{3}
\end{aligned}
$$

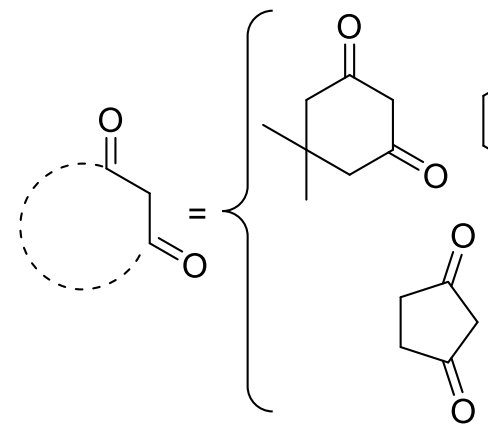<smiles>O=C1CCCC(=O)C1</smiles><smiles>O=C1CC(=O)CC(c2ccccc2)C1</smiles><smiles>CCCCCCCCC=O</smiles>

Scheme 3. Wang's four-component synthesis of polyfunctionalized pyrroles. ${ }^{76}$

Mehrabi and coworkers reported similar reactions but under rather milder conditions. To explore the scope of this transformation a series of pyrrole derivatives $\mathbf{1 1}$ was prepared in a one-pot four-component reaction; a mixture of various aromatic amines 8 with arylglyoxals 4, dialkyl acetylenedicarboxylate $\mathbf{3}$ and Meldrum's acid or dimedone $\mathbf{1 0}$ was stirred in ethanol at room temperature (Scheme 4). Again, excellent yields were reported. ${ }^{77}$

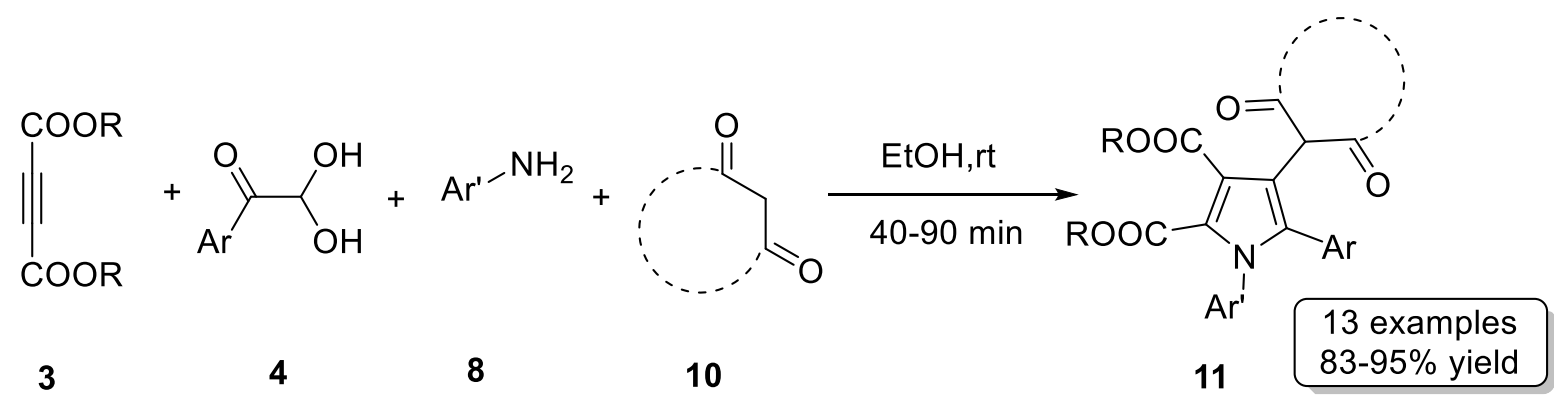

$\mathrm{R}=\mathrm{Me}, \mathrm{Et}$

$\mathrm{Ar}=\mathrm{Ph}, 4-\mathrm{ClC}_{6} \mathrm{H}_{4}, 4-\mathrm{MeC}_{6} \mathrm{H}_{4}, 4-\mathrm{BrC}_{6} \mathrm{H}_{4}$ $\mathrm{Ar}^{\prime}=\mathrm{Ph}, 4-\mathrm{ClC}_{6} \mathrm{H}_{4}, 4-\mathrm{MeC}_{6} \mathrm{H}_{4}, 4-\mathrm{MeOC}_{6} \mathrm{H}_{4}$

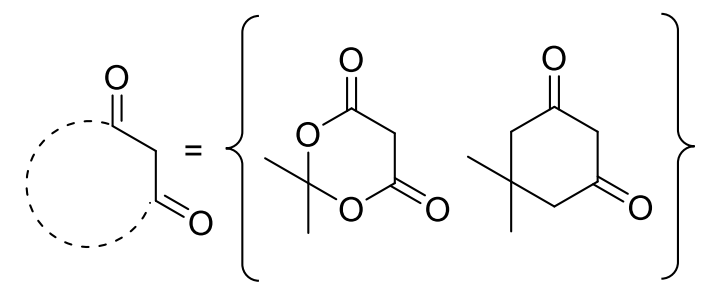

Scheme 4. Four-component synthesis of polysubstituted pyrroles described by Mehrabi et al. ${ }^{77}$ 
A very efficient synthesis of the polysubstituted pyrroles 12 and $\mathbf{1 5}$, was reported by Shi and coworkers. A 1:1:1:1 mixture of arylglyoxals 4, anilines 8, dialkyl acetylenedicarboxylates $\mathbf{3}$ or alkyl acetoacetates 13, and malononitrile 14 in the presence of the phase-transfer catalyst TEBAC in ethanol as solvent at reflux temperature, was found to lead to pyrroles (Scheme 5). ${ }^{78}$

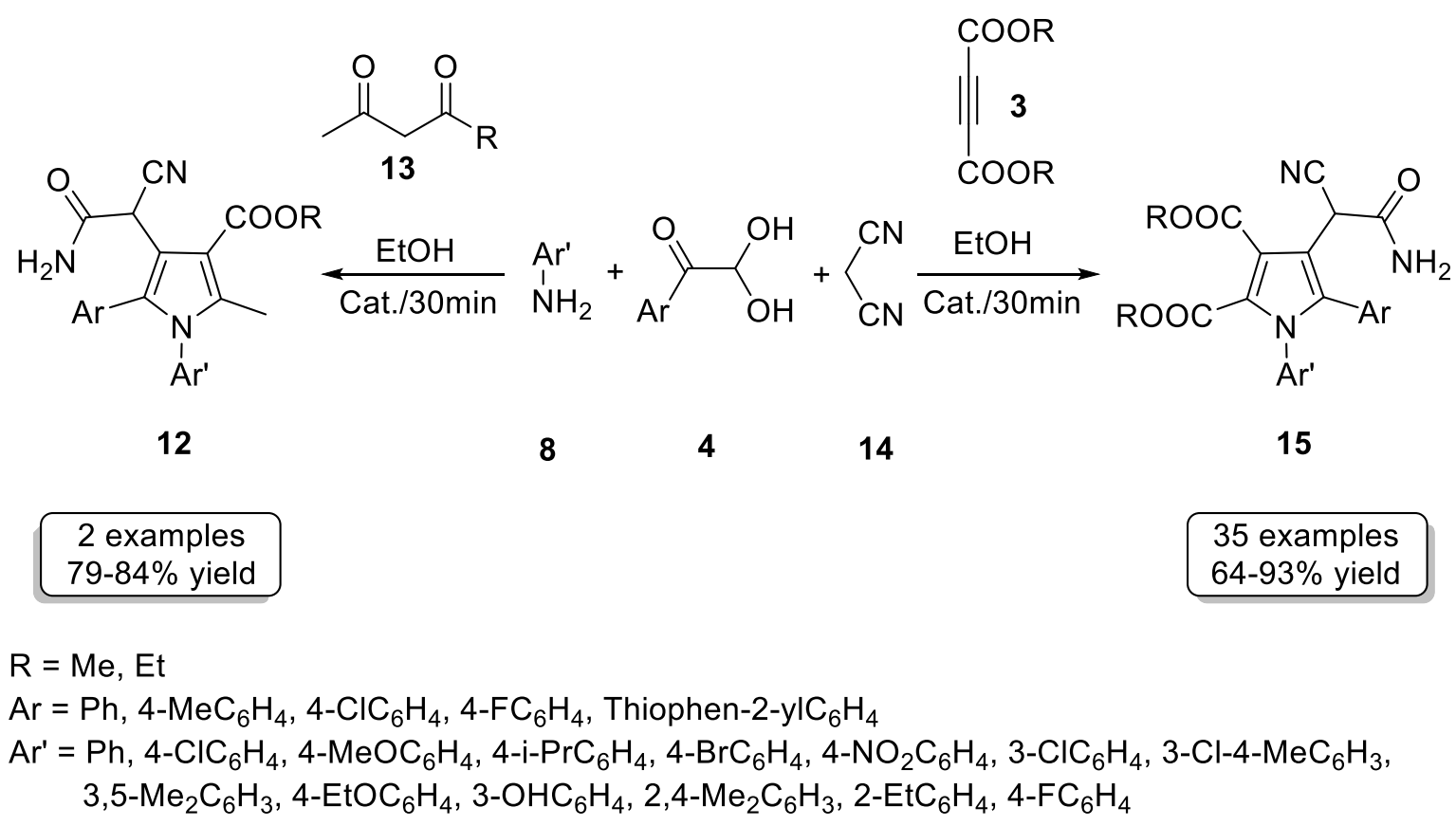

Scheme 5. Synthesis of pyrroles developed by Shi and co-workers. ${ }^{78}$

For the synthesis of polysubstituted pyrroles 17, Dhinakaran and coworkers have developed an efficient domino protocol from the one-pot, three-component domino reactions of arylglyoxals 4, malononitrile 14 and ethyl (E)-3-(4-arylamino)acrylates 16 under solvent- and catalyst-free conditions simply by grinding (Scheme $6) .^{79}$

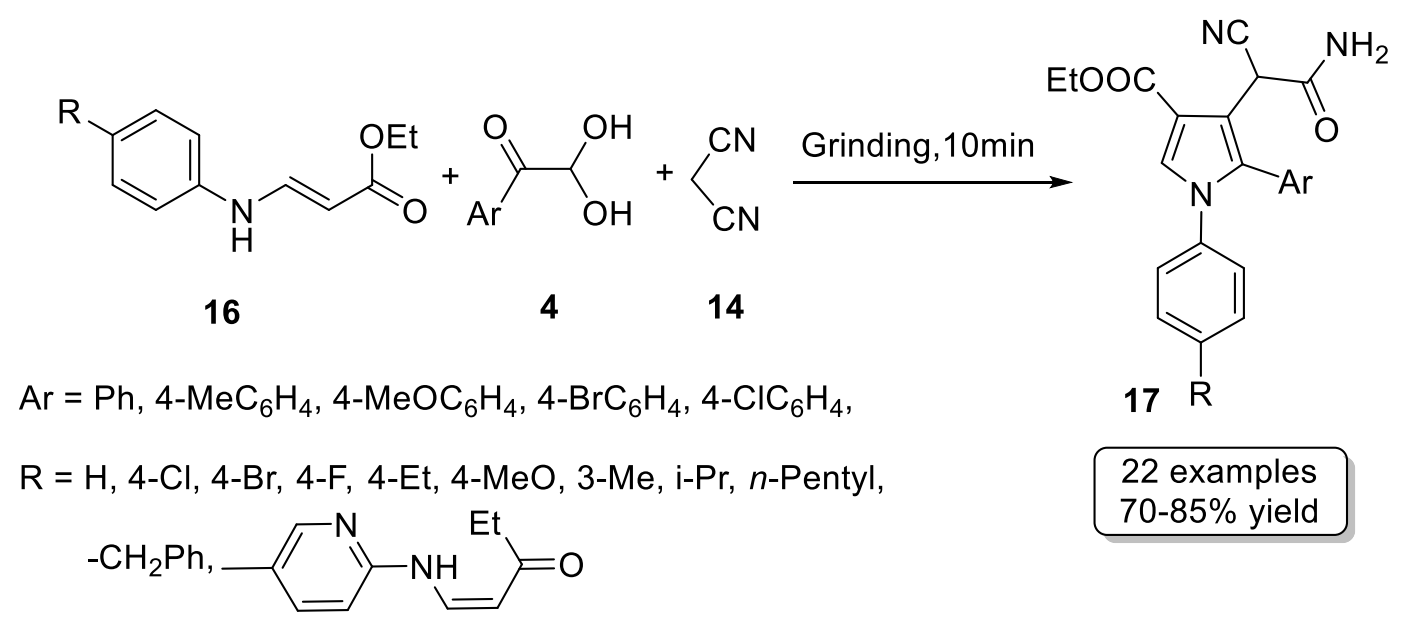

Scheme 6. Three-component synthesis of multifunctionalized pyrroles. ${ }^{79}$ 
The polysubstituted pyrroles $\mathbf{2 1}$ have been synthesized via a coupling reaction involving acetophenone 18, $\mathrm{N}, \mathrm{N}$-dimethylformamide dimethylacetal 19, substituted amines 8 , arylglyoxals 4 and malononitrile 14 in methanol under reflux, leading to the novel pyrrole cyanoacetamides $\mathbf{2 1}$ in good yields (Scheme 7). ${ }^{80}$

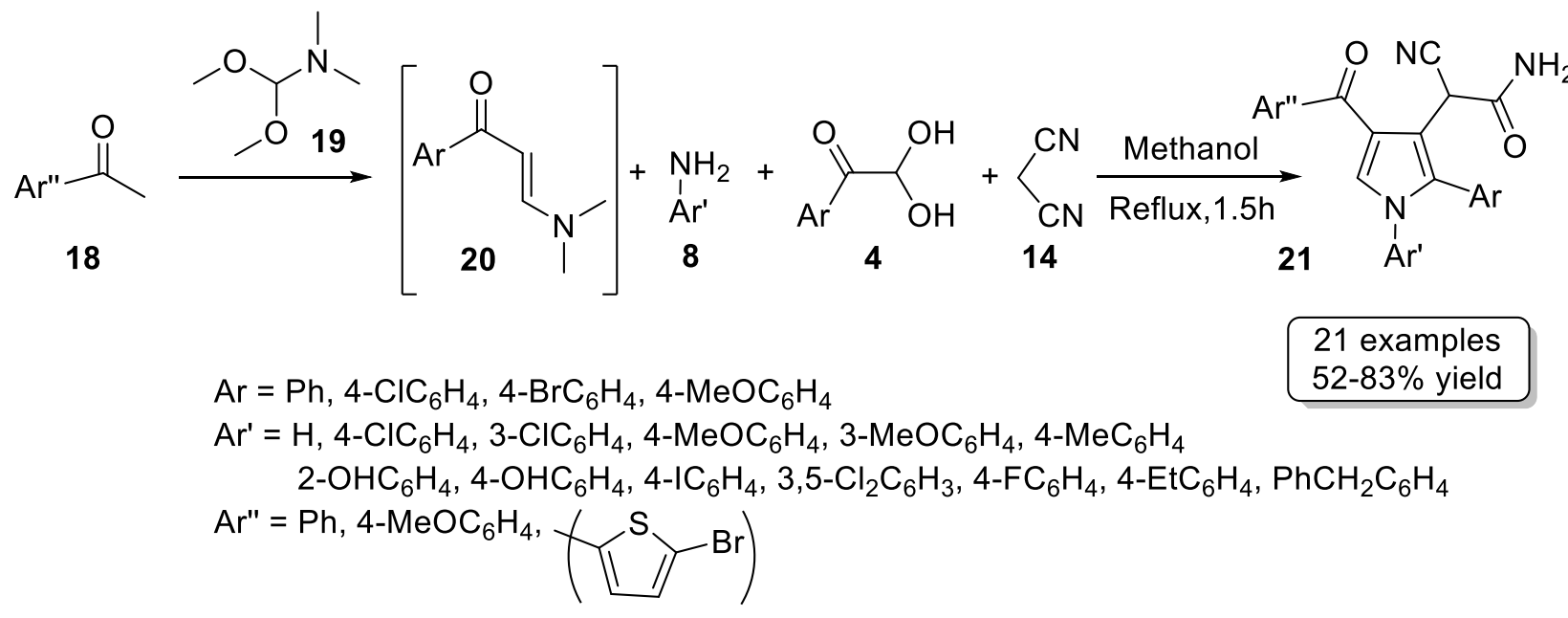

Scheme 7. Synthesis of substituted pyrroles developed by Ambethkar. ${ }^{80}$

Eftekhary-Sis et al. reported an efficient and facile procedure for the synthesis of pyrrole heterocycles 24 by the reaction of various substituted arylglyoxals $\mathbf{4}$ and $\beta$-dicarbonyl compounds 22 in the presence of ammonium acetate $\mathbf{2 3}$ under ultrasound irradiation (US) (Scheme 15). ${ }^{81}$

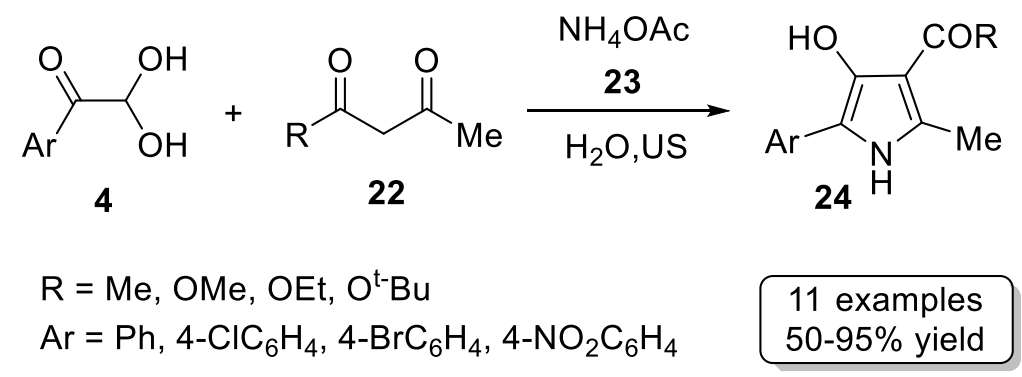

Scheme 8. Ultrasound-assisted synthesis of pyrrole derivatives. ${ }^{81}$

Further research into the synthesis of tetrasubstituted pyrroles $\mathbf{2 4}$ by Bhat's group with the reaction of 1,3-dicarbonyls 22, and arylglyoxals $\mathbf{4}$ with ammonium acetate $\mathbf{2 3}$ under solvent- and catalyst-free conditions yielded only one regioisomer (Scheme 16). ${ }^{82}$

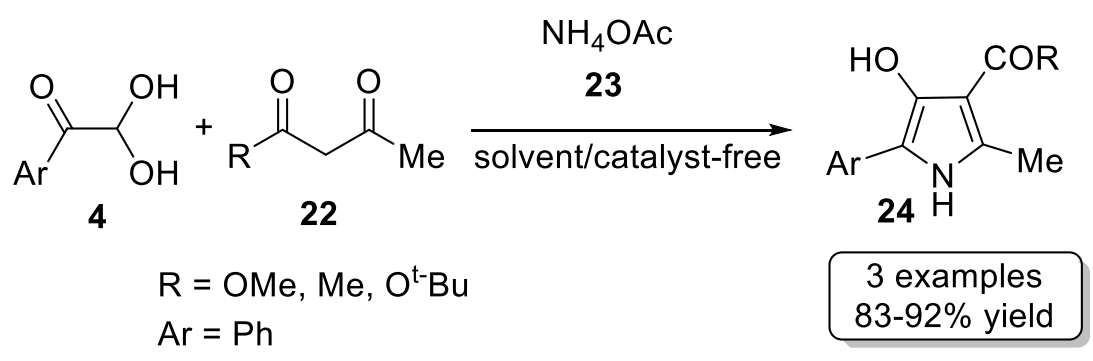

Scheme 9. Synthesis of fully substituted pyrroles reported by Bhat. ${ }^{82}$ 
Anary-Abbasinejad's group has reported a green MCR approach for the synthesis of a series of pyrrole derivatives 26. Thus, the four-component domino reaction between arylglyoxals 4, acetylacetone 22', indole 25 and aliphatic amines in water as a solvent in the absence of any catalyst afforded indole derivatives in excellent yields (Scheme 10). ${ }^{83}$

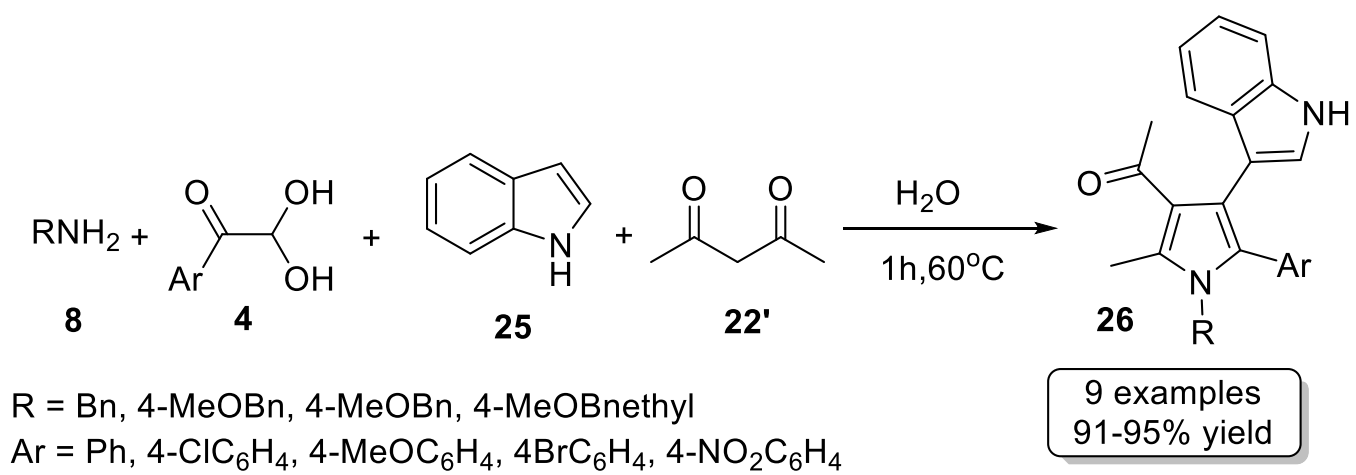

Scheme 10. Four-component synthesis of indolyl pyrroles. ${ }^{83}$

Looking further into this reaction, Anary-Abbasinejad and his group studied the three-component reaction between arylglyoxals 4, acetylacetone 22 and enaminoketones 27 (Scheme 11). ${ }^{84} \mathrm{~A}$ mixture of 4 and acetylacetone 22 was stirred in water at $100{ }^{\circ} \mathrm{C}$. Then 27 was added and the mixture was heated at $100{ }^{\circ} \mathrm{C}$, to afford pure 3-acetyl-4-(4-bromobenzoyl)-5-[1-(p-tolylamino)ethylidene]heptane-2,6-dione 28. When the reaction was carried out in 1:1 water-ethanol mixture in the presence of $10 \mathrm{~mol} \%$ of $\mathrm{NaOH}$ under reflux conditions, one of the acetyl groups of an acetylacetone moiety of $\mathbf{2 8}$ was removed and the only isolated product was the pyrrole derivative 30. Similar results were obtained when $\mathrm{Et}_{3} \mathrm{~N}$ was used as catalyst under reflux condition for the synthesis of pyrrole derivative 29.

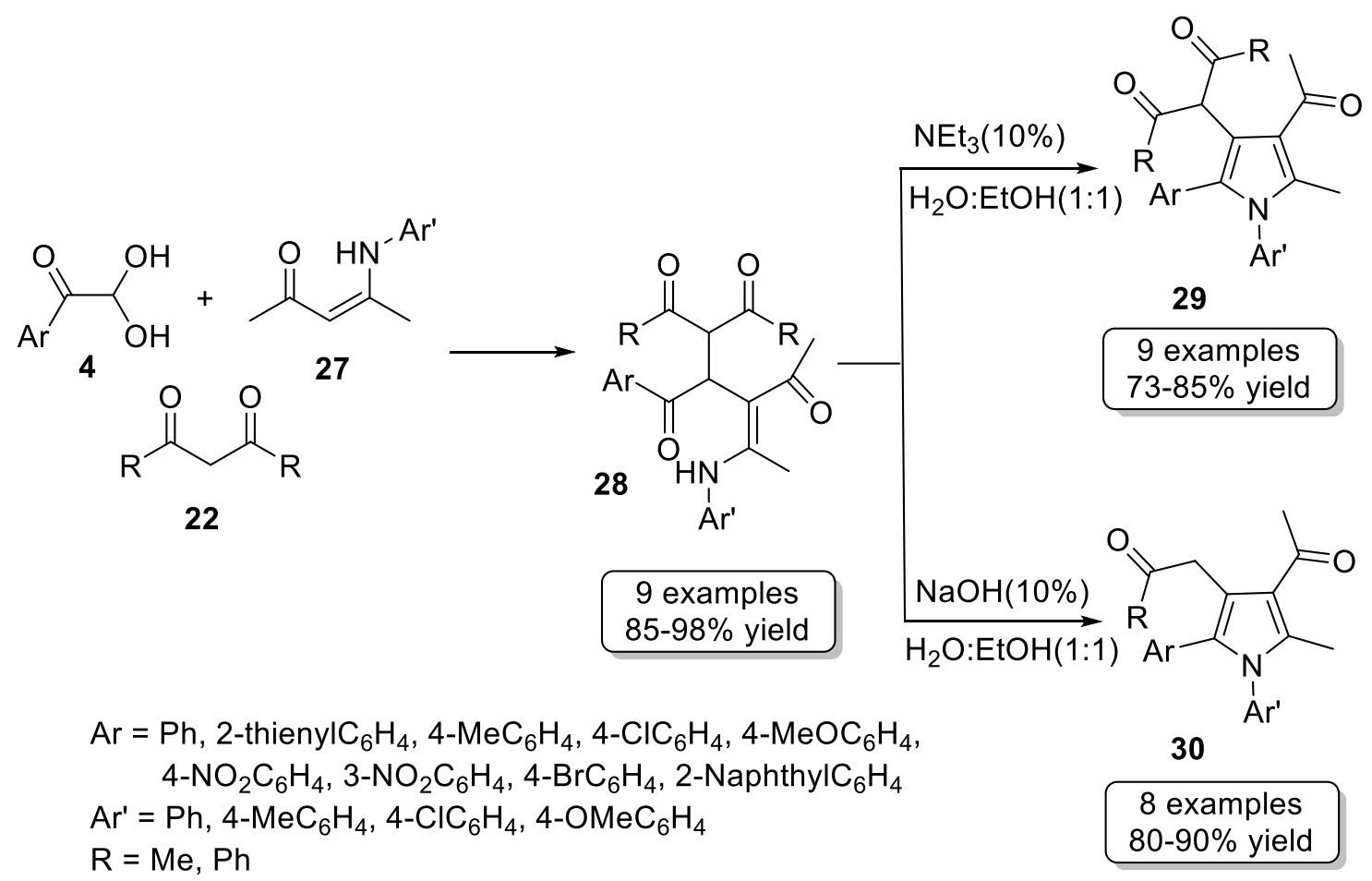

Scheme 11. Three-component synthesis of multifunctionalized pyrroles. ${ }^{84}$ 
The polysubstituted pyrrole derivatives 35-38 were prepared by Choudhury and co-workers in fourcomponent reactions between cyclic 1,3-dicarbonyl compounds 31-34, $\beta$-keto esters 22, arylglyoxals 4 and amines 8 under catalyst-free conditions as shown in Scheme $12 .{ }^{85}$

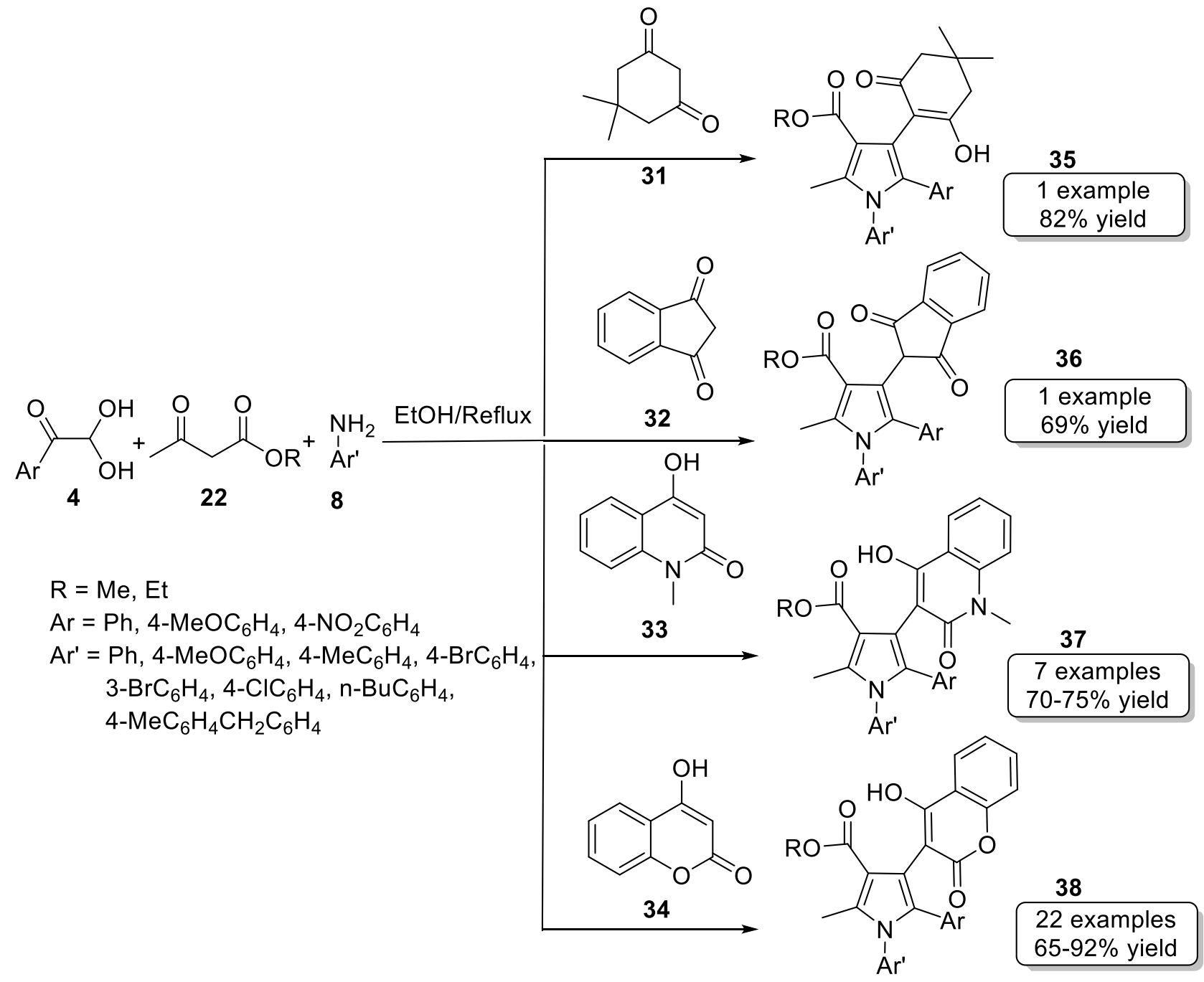

Scheme 12. One-pot synthesis of substituted pyrroles. ${ }^{85}$

A one-pot multicomponent process has been developed by Dommaraju and Prajapati for the formation of poly-functionalized pyrimidin-5-yl-pyrroles $\mathbf{4 0}$ and $\mathbf{4 1}$ by reacting equimolar amounts of various anilines $\mathbf{8}$, barbituric acid derivatives $\mathbf{3 9}$, arylglyoxals $\mathbf{4}$ and ethyl acetoacetate $\mathbf{2 2}$ or dialkyl acetylenedicarboxylates $\mathbf{3}$, in ethanol as solvent under reflux conditions (Scheme 13). ${ }^{86}$ 


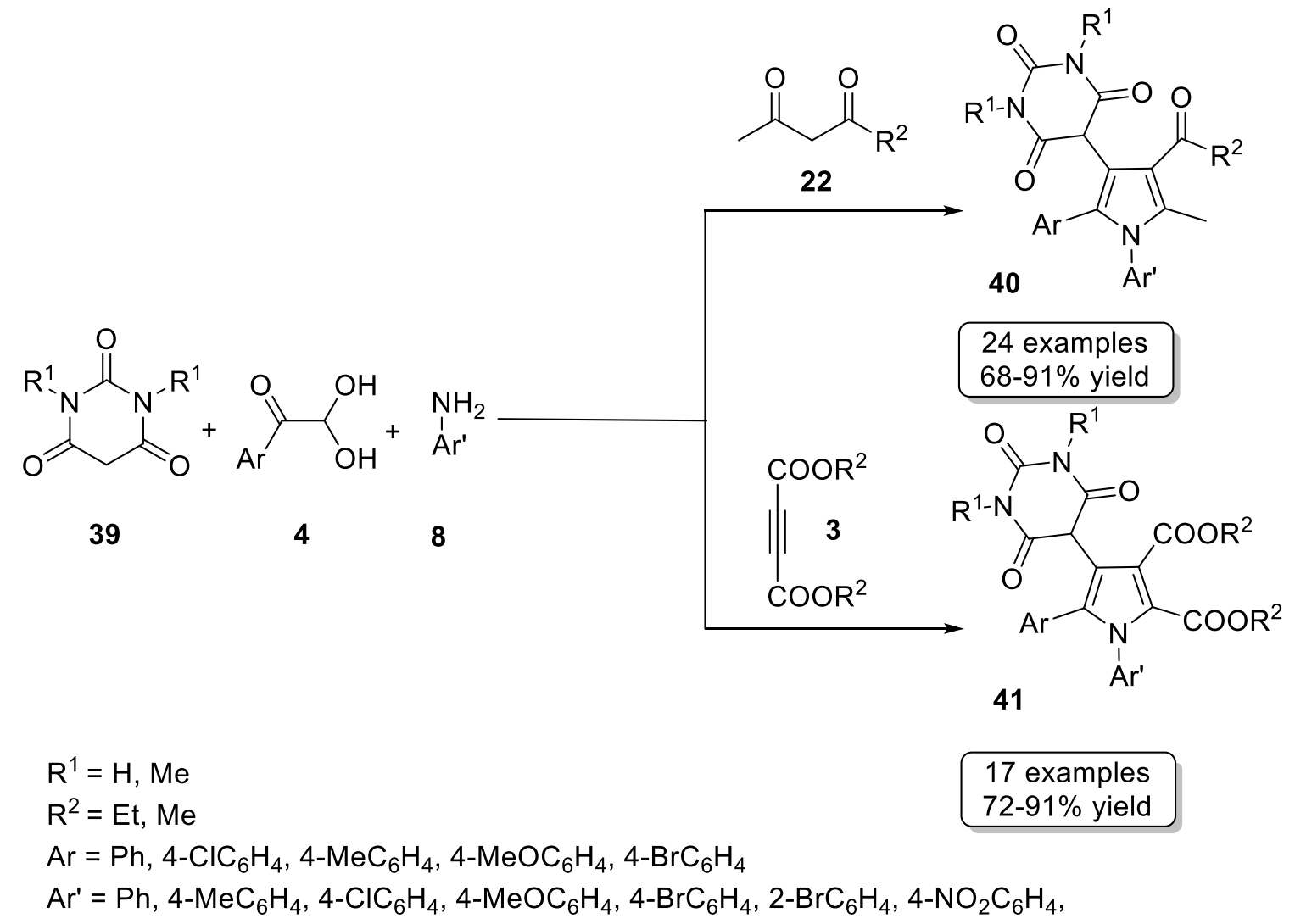

Scheme 13. Three-component synthesis of pyrroles. ${ }^{86}$

In addition, when 1,2-diaminoethane $\mathbf{4 2}$ was used as a substrate, the 1,2-bispyrrole derivative $\mathbf{4 3}$ was obtained in moderate yield (Scheme 14). When the reaction was performed with the reactants in stoichiometric ratios under same conditions the desired product was obtained in good yield.<smiles>COCCCC(C)OC</smiles>

39<smiles>O=C(c1ccccc1)C(O)O</smiles>

4<smiles>N[C+]CC[NH3+]</smiles>

42<smiles>CCOC(=O)CC(C)=O</smiles>

22<smiles>CCOC(=O)c1cn(CCn2cc(C(=O)OCC)c(C3C(=O)N(C)C(=O)N(C)C3=O)c2-c2ccc(OC)cc2)c(-c2ccc(C)cc2)c1C</smiles>

1 example $71 \%$ yield

Scheme 14. Multicomponent syntheses of a bispyrrole derivative. ${ }^{86}$

Other bispyrroles formed from a diamine are compounds 44, prepared by Choudhury et al. ${ }^{85}$ from p-phenylenediamine with ethyl or methyl acetoacetate, phenylglyoxal 4, and 4-hydroxycoumarin 34. 


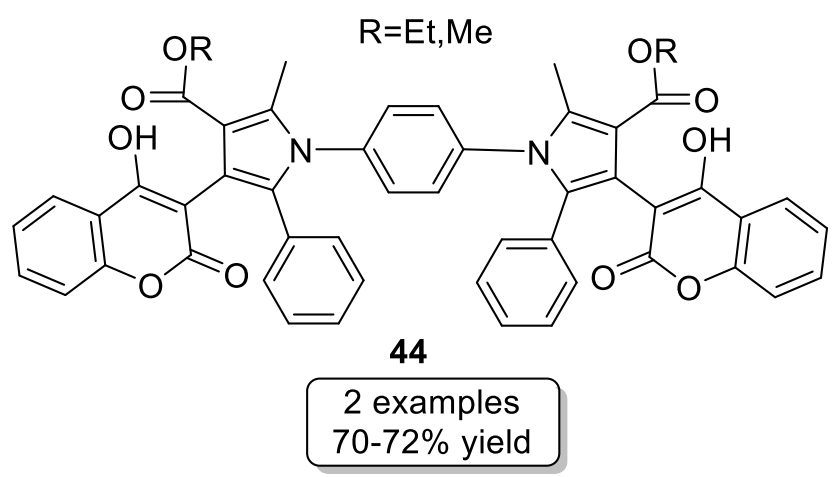

Chen et al. reported a highly efficient one-pot regioselective synthesis of pyrrole derivatives $\mathbf{4 8}$ by a sequential reaction of nitriles with $\alpha$-bromoesters and arylglyoxals 4 (Scheme 15). ${ }^{87}$ The Blaise reaction intermediate $\mathbf{4 7}$ was generated in situ from the reaction of benzonitrile $\mathbf{4 5}$ with the bromoestert $\mathbf{4 6}$ in THF under catalyst-free condition. The tandem reaction of the intermediate $\mathbf{4 7}$ with arylglyoxals proceeded smoothly in THF under room temperature for $\mathbf{3 0 ~} \mathrm{min}$ to afford the corresponding pyrroles $\mathbf{4 8}$ in good yields.

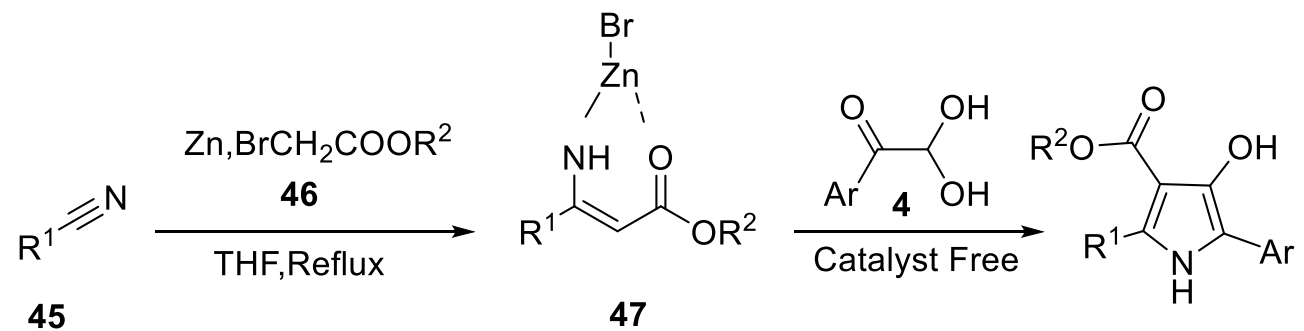

$$
\begin{aligned}
\mathrm{R}^{1}= & \operatorname{Aryl}\left(\mathrm{Ph}, 2-\mathrm{ClC}_{6} \mathrm{H}_{4}, 2-\mathrm{MeC}_{6} \mathrm{H}_{4}, 4-\mathrm{FC}_{6} \mathrm{H}_{4}, 4-\mathrm{MeC}_{6} \mathrm{H}_{4}\right), \mathrm{Me}, \mathrm{n}-\mathrm{Bu} \\
\mathrm{R}^{2}= & \mathrm{Et}, \mathrm{t}-\mathrm{Bu} \\
\mathrm{Ar}= & \mathrm{Ph}, 4-\mathrm{ClC}_{6} \mathrm{H}_{4}, 4-\mathrm{MeC}_{6} \mathrm{H}_{4}, 3,4-(\mathrm{MeO})_{2} \mathrm{C}_{6} \mathrm{H}_{3}, 2-\mathrm{MeC}_{6} \mathrm{H}_{4}, 3-\mathrm{ClC}_{6} \mathrm{H}_{4}, 2-\mathrm{ClC}_{6} \mathrm{H}_{4}, \\
& 4-\mathrm{FC}_{6} \mathrm{H}_{4}, 4-\mathrm{NO}_{2} \mathrm{C}_{6} \mathrm{H}_{4}, 4-\mathrm{MeOC}_{6} \mathrm{H}_{4}
\end{aligned}
$$

Scheme 15. Two-step synthesis of pyrroles via the Blaize reaction. ${ }^{87}$

Liu et al. have reported the synthesis of indolyl-substituted pyrroles $\mathbf{5 0}$ by the reaction of arylglyoxals $\mathbf{4}$ with the dithioacetal 49, aniline 8 and 2-methylindole 25 in nitromethane using $\mathrm{AlCl}_{3}$ as catalyst in a fourcomponent reaction (Scheme 16). ${ }^{88}$

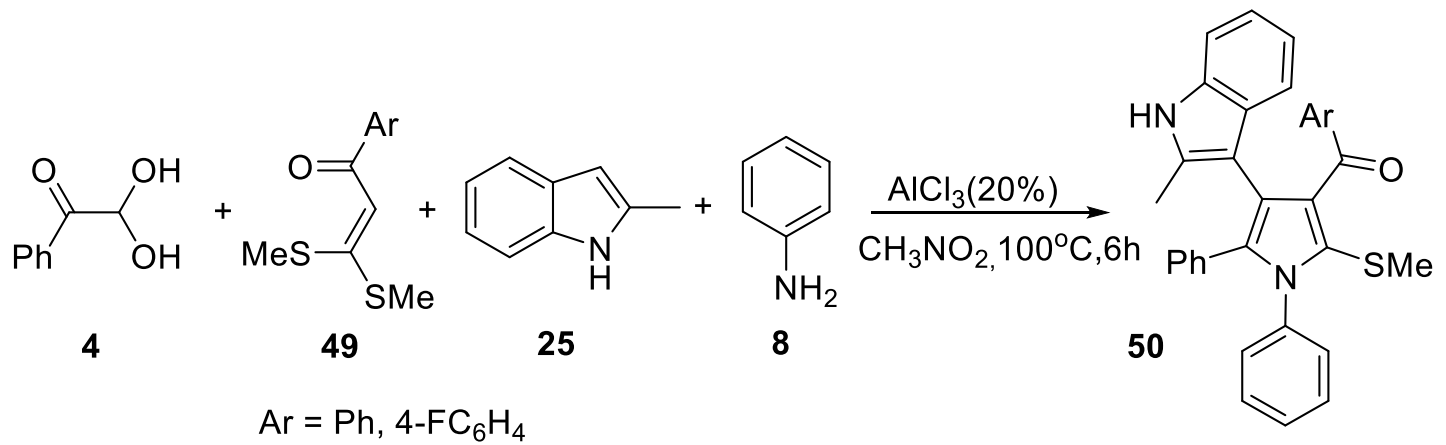

$$
\mathrm{Ar}=\mathrm{Ph}, 4-\mathrm{FC}_{6} \mathrm{H}_{4}
$$

Scheme 16. Four-component synthesis of multifunctionalized pyrroles. ${ }^{88}$ 
A convenient method for the synthesis of polysubstituted pyrrole scaffolds has been reported by Kolos and co-workers. ${ }^{89}$ Refluxing of arylglyoxals 4, acetoacetic ester or its derivatives 52, and substituted anilines 8 in methanol with added catalytic amounts of acetic acid was found to result in precipitation of substituted pyrroles $\mathbf{5 1}$ or $\mathbf{5 3}$ from the hot reaction mixture after 30 min (Scheme 17).

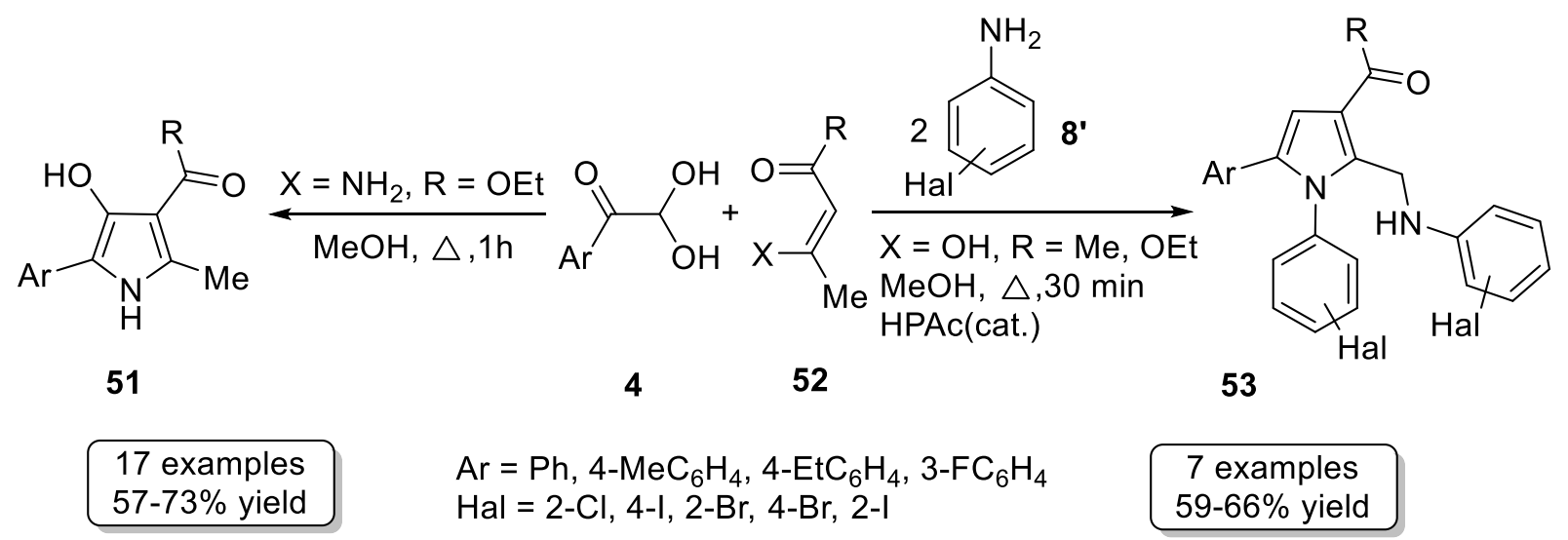

Scheme 17. One-pot reaction of substituted pyrroles. ${ }^{89}$

Liu et al. reported the highly efficient annulation of enaminones $\mathbf{2 7}$ with arylglyoxals 4 and indoles 25', thiophenol 54 or arylamines 8", yielding fully substituted pyrroles 55-57 via three-component domino reactions involving indolisation and thiolation processes (Scheme 18). ${ }^{90}$

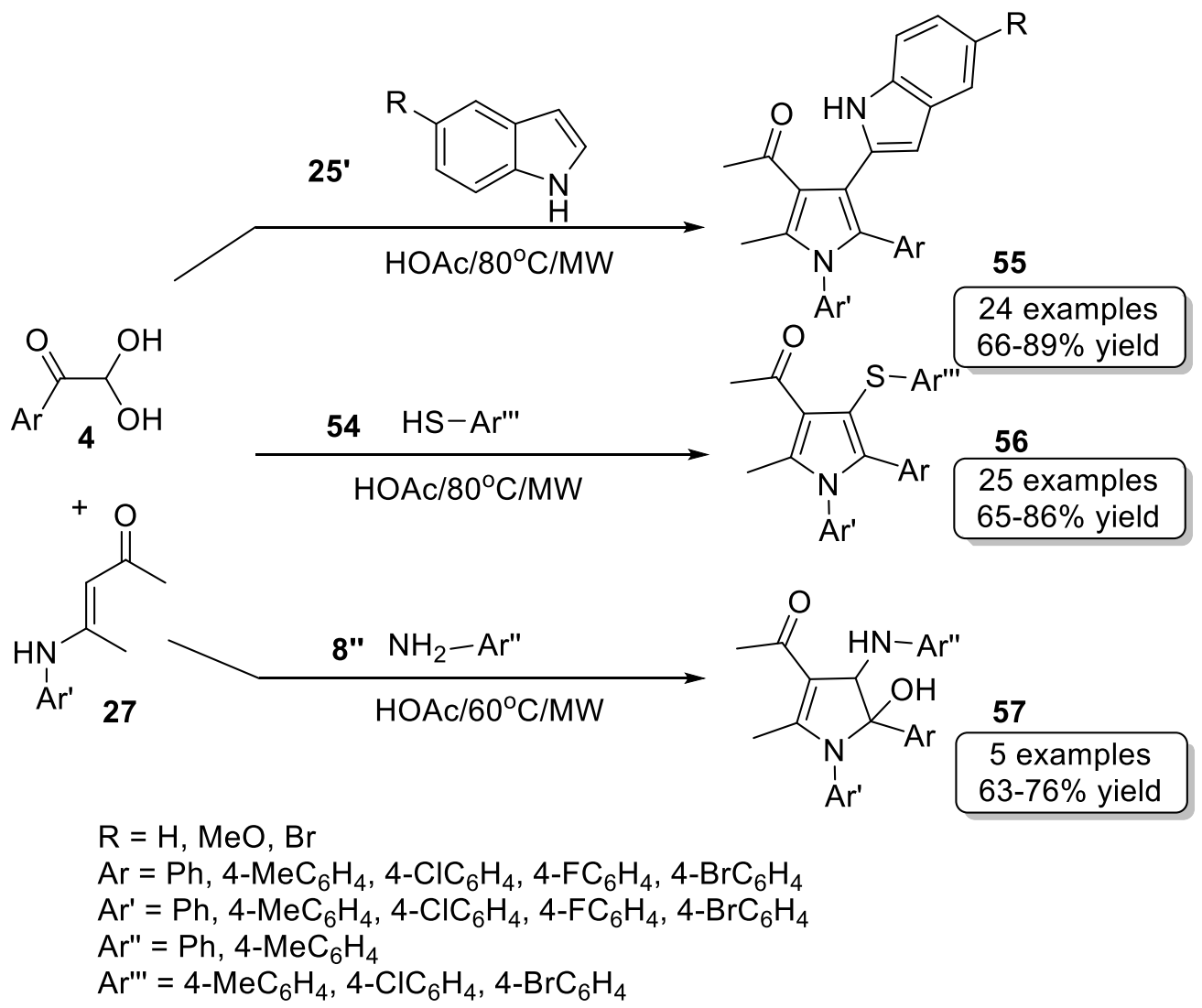

Scheme 18. Three-component pyrrole synthesis of Liu et al. ${ }^{90}$ 
The synthesis of pyrrole derivatives 58 was accomplished by Masoudi and Anary-Abbasinejad using the reaction between arylglyoxals 4 with 4-phenylamino-3-pentene-2-one 27 in acetonitrile (Scheme 19). ${ }^{91}$ Triphenylphosphine $\mathbf{1}$ was added after 10 min of stirring, to form substituted pyrrole $\mathbf{5 8}$ and triphenylphosphine oxide.

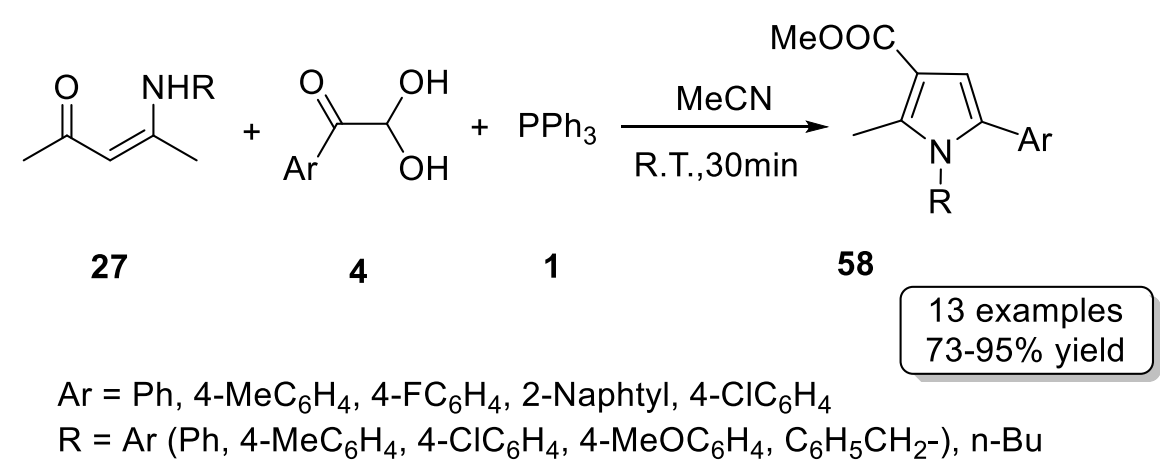

Scheme 19. Anary-Abbasinejad's three-component synthesis of polyfunctionalized pyrroles. ${ }^{91}$

Considering the significance of iodine-mediated oxidation of methyl ketones, Jalani et al. investigated the one-pot synthesis of substituted pyrroles under the influence of a co-product promoted Povarov reaction of acetophenone $\mathbf{1 8}$, arylamines $\mathbf{8}$, and a-keto esters $\mathbf{5 9}$. They used enamine such as methyl-3-aminobut-2enoate instead of a-keto esters to permit the nucleophilic addition of enamines to the C-acylimine ion, which could then be followed through intramolecular cyclization to the formation of 4-aminopyrroles 60 (Scheme 20). ${ }^{92}$

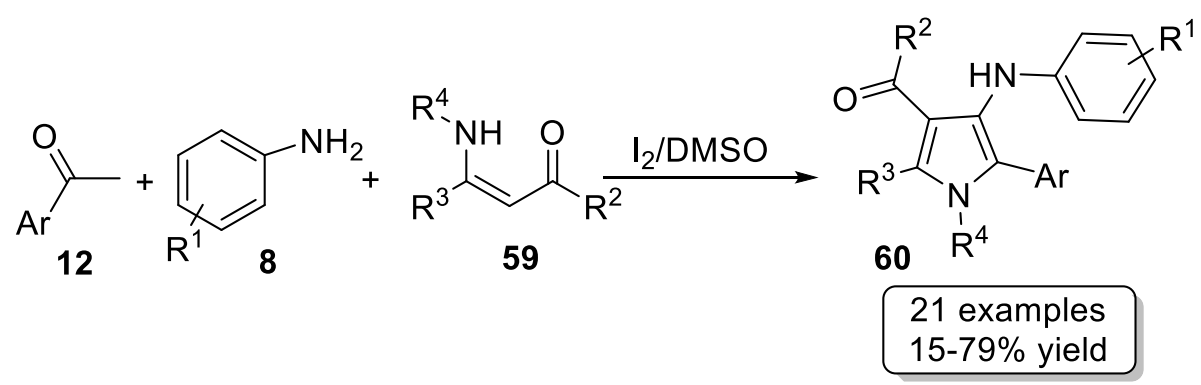

$$
\begin{aligned}
& \mathrm{Ar}=\mathrm{Ph}, 4-\mathrm{MeOC}_{6} \mathrm{H}_{4}, 3,5-(\mathrm{MeO})_{2} \mathrm{C}_{6} \mathrm{H}_{3}, 2-\mathrm{BrC}_{6} \mathrm{H}_{4}, 4-\mathrm{ClC}_{6} \mathrm{H}_{4}, 2-\mathrm{MeC}_{6} \mathrm{H}_{4}, 4-\mathrm{PhC}_{6} \mathrm{H}_{4} \\
& \mathrm{R}^{1}=\mathrm{H}, 4-\mathrm{MeO}, 3,5-\mathrm{Cl}_{2}, 4-\mathrm{NO}_{2}, 4-\mathrm{Cl}, 4-\mathrm{Me}, 2-\mathrm{Py}, 3,5-(\mathrm{i}-\mathrm{Bu})_{2}, 1-\mathrm{Naphthyl} \\
& \mathrm{R}^{2}=\mathrm{MeO}, \mathrm{EtO},{ }^{\mathrm{t}} \mathrm{BuO} \\
& \mathrm{R}^{3}=\mathrm{Me}, 3-\mathrm{MeC}_{6} \mathrm{H}_{4}, \mathrm{Ph}, 2-\mathrm{FC}_{6} \mathrm{H}_{4}, 4-\mathrm{MeOC}_{6} \mathrm{H}_{4}, \mathrm{i}-\mathrm{Bu}, 2-\mathrm{Thienyl} \text {, Diphenyl } \\
& \mathrm{R}^{4}=\mathrm{H}, 4-\mathrm{MeOC}_{6} \mathrm{H}_{4}
\end{aligned}
$$

Scheme 20. Multicomponent syntheses of pyrroles reported by Jalani et al. ${ }^{92}$

\subsection{Synthesis of 1,5,6,7-dihydro-4H-indol-4-ones and other indoles}

Recently, a four-component reaction leading to the fused pyrrole derivatives $\mathbf{6 1}$ and $\mathbf{6 4}$ was reported: the reaction of dimedone $\mathbf{3 1}$ and various anilines $\mathbf{8}$ proceeds by one-pot reaction under solvent-free conditions at $80{ }^{\circ} \mathrm{C}$ to produce the enaminone adduct intermediate 63 . The sequential addition of arylglyoxals 4 and malononitrile $\mathbf{1 4}$ or ethyl cyanoacetate or methyl cyanoacetate $\mathbf{6 2}$ in ethanol successfully gave the desired product in good yields. It is noteworthy that when malononitrile $\mathbf{1 4}$ was used, the reaction led to the 
formation of $\mathbf{6 4}$ in excellent yield, whereas using and using ethyl or methyl cyanoacetate $\mathbf{6 2}$ led to product $\mathbf{6 1}$ (Scheme 21). ${ }^{93}$

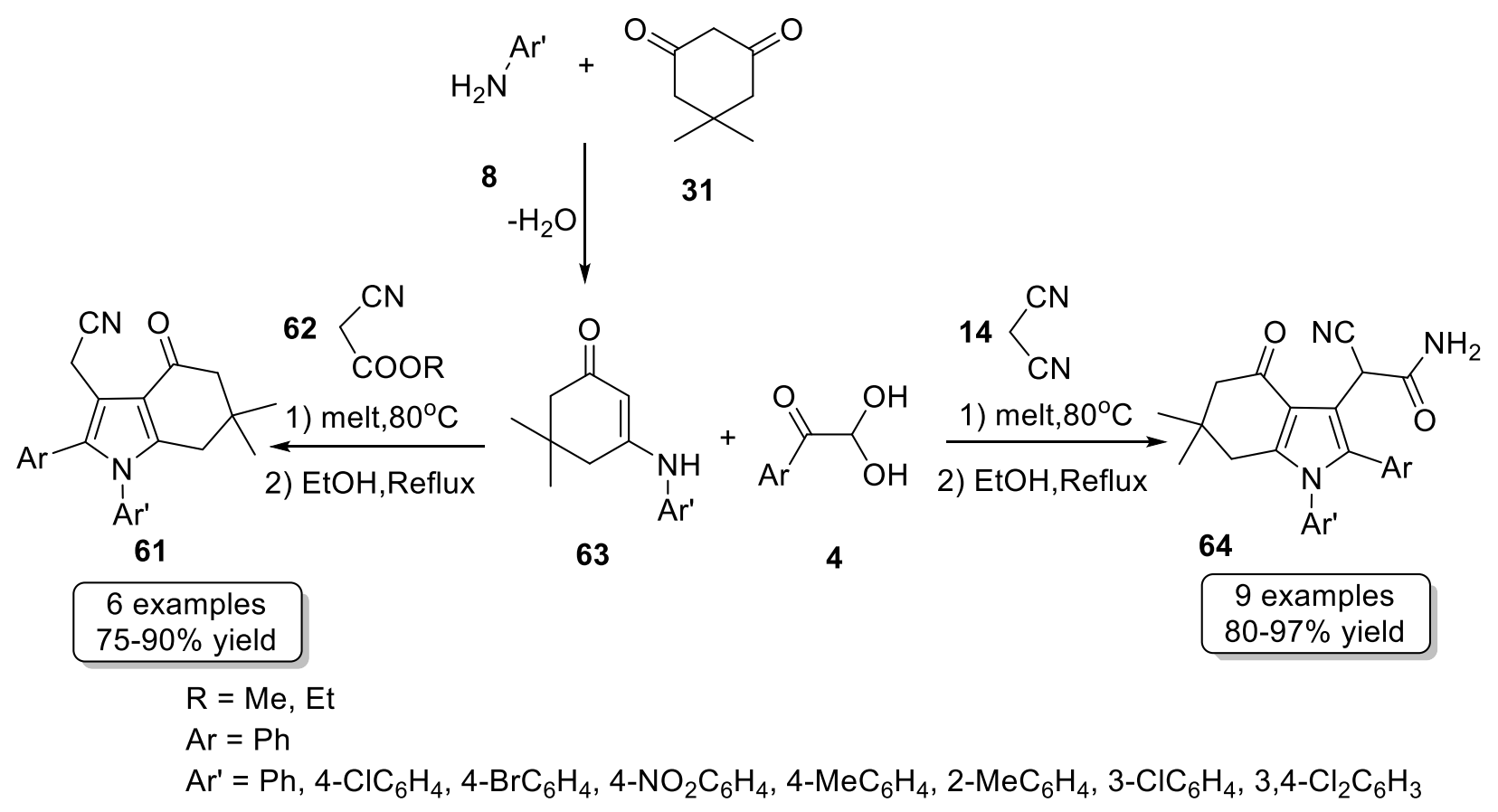

Scheme 21. Four-component synthesis of fused pyrroles developed by Bayat et al. ${ }^{93}$

Recently, Indian researchers have reported that the domino condensation of arylglyoxals 4 , enaminones 63, and malononitrile 14 can produce highly substituted pyrrole and tetrahydroindole derivatives, e.g. 64', in high yield by a one-pot reaction (Scheme 22). ${ }^{94}$

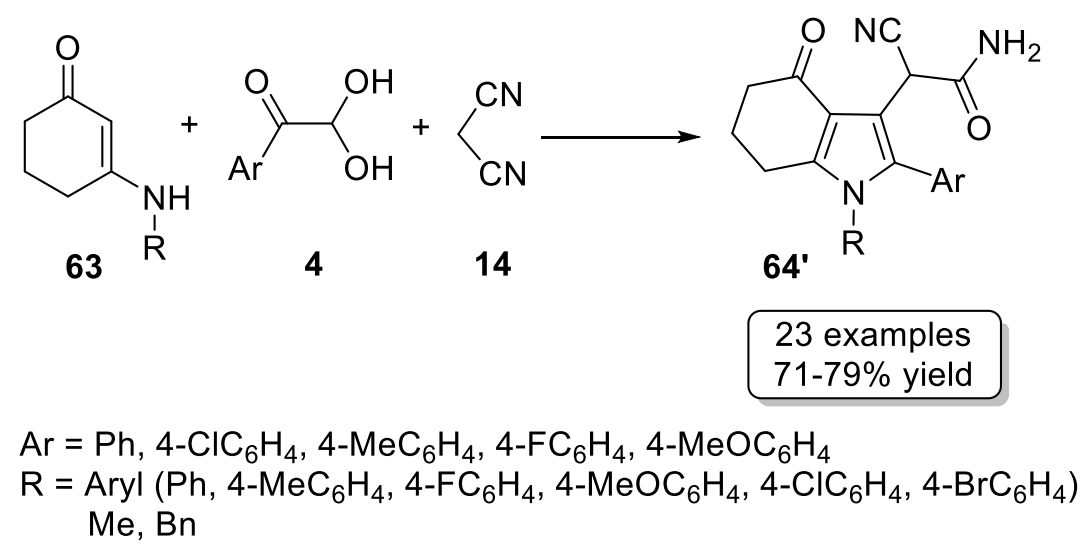

Scheme 22. Synthesis of tetrahydroindoles from arylglyoxals, enamines and malononitrile. ${ }^{94}$

Wang and Shi studied the three-component reaction of 1,3-dicarbonyl compounds 10, arylglyoxals 4, and enaminone 63 (Scheme 23) for the synthesis of functionalized dihydro- $1 H$-indol-4(5H)-ones 65 via one-pot three-component reactions under catalyst-free conditions. ${ }^{95}$ The reaction mixture was tested under a variety of different conditions to study the effects of solvent and temperature. 


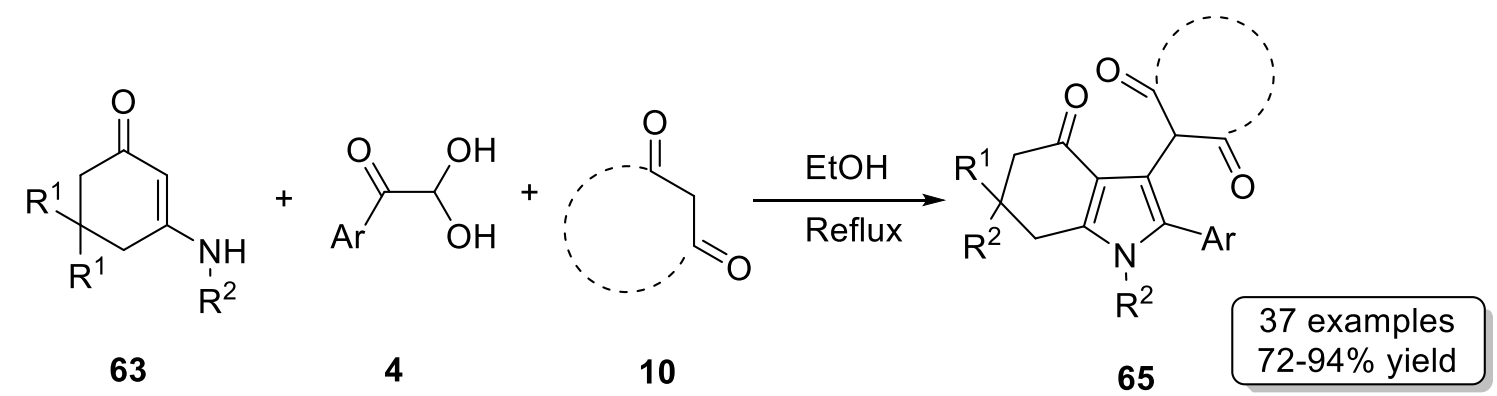

$\mathrm{R}^{1}=\mathrm{H}, \mathrm{Me}$

$\mathrm{R}^{2}=\operatorname{Aryl}\left(\mathrm{Ph}, 4-\mathrm{MeC}_{6} \mathrm{H}_{4}, 4-\mathrm{ClC}_{6} \mathrm{H}_{4}, 4-\mathrm{BrC}_{6} \mathrm{H}_{4}, 4-\mathrm{MeOC}_{6} \mathrm{H}_{4}, 4-\mathrm{NO}_{2} \mathrm{C}_{6} \mathrm{H}_{4}, 3-\mathrm{ClC}_{6} \mathrm{H}_{4}, 3-\mathrm{ClC}_{6} \mathrm{H}_{4}\right.$, 4- $-\mathrm{MeC}_{6} \mathrm{H}_{4}, 3,5-\mathrm{Me}_{2} \mathrm{C}_{6} \mathrm{H}_{3}, 4-\mathrm{i}-\mathrm{PrC}_{6} \mathrm{H}_{4}, 4-\mathrm{i}-\mathrm{BuC}_{6} \mathrm{H}_{4}, 4-\mathrm{FC}_{6} \mathrm{H}_{4}, 3-\mathrm{ClC}_{6} \mathrm{H}_{4}$ ), Bu $\mathrm{Ar}=\mathrm{Ph}, 4-\mathrm{MeC}_{6} \mathrm{H}_{4}, 4-\mathrm{ClC}_{6} \mathrm{H}_{4}, 4-\mathrm{BrC}_{6} \mathrm{H}_{4}, 4-\mathrm{MeOC}_{6} \mathrm{H}_{4}$

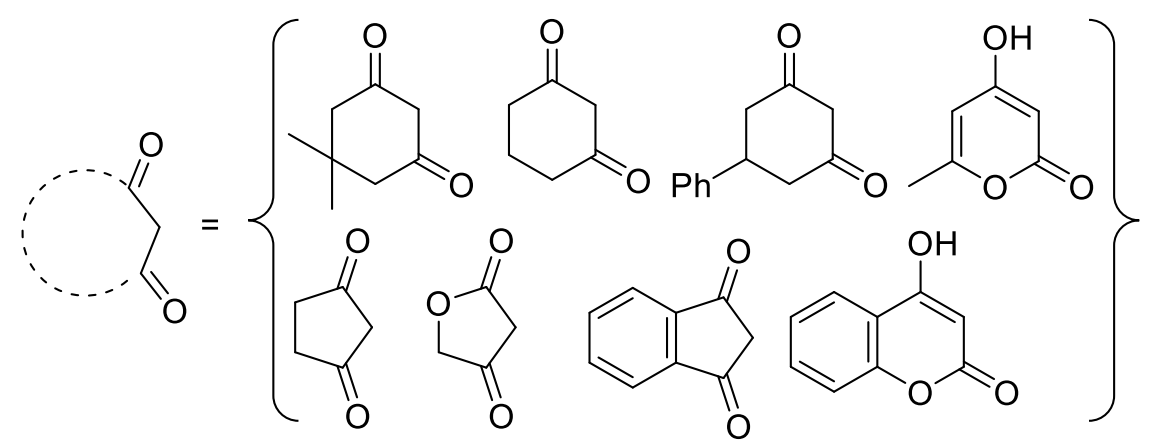

Scheme 23. Three-component synthesis of 6,7-dihydroindol-4(5H)-ones. ${ }^{95}$

During another study of this topic, there was reported the three-component domino [3+2] heterocyclization of arylglyoxals $4, \mathrm{~N}$-arylenaminones 63 , and 4-hydroxy-6-methyl- $2 \mathrm{H}$-pyran-2-one 66 , providing fused pyrroles 65 on microwave irradiation in the presence of acetic acid (Scheme 24). ${ }^{96}$ The attractive aspect of this reaction is the fact that the construction of the pyrrole skeleton and the direct C3 pyranation were readily achieved in an intermolecular fashion in a single process.<smiles>CC1=CC(O)C(c2c3c(n([Al])c2[Al])CC(C)(C)CC3=O)C(=O)O1</smiles>

63

4

66

65

$\mathrm{Ar}^{\prime}=\mathrm{Ph}, 4-\mathrm{FC}_{6} \mathrm{H}_{4}, 4-\mathrm{ClC}_{6} \mathrm{H}_{4}, 4-\mathrm{BrC}_{6} \mathrm{H}_{4}, 4-\mathrm{IC}_{6} \mathrm{H}_{4}, 3-\mathrm{BrC}_{6} \mathrm{H}_{4}, 4-\mathrm{MeC}_{6} \mathrm{H}_{4}, 4-\mathrm{MeOC}_{6} \mathrm{H}_{4}$ $\mathrm{Ar}=\mathrm{Ph}, 4-\mathrm{FC}_{6} \mathrm{H}_{4}, 4-\mathrm{ClC}_{6} \mathrm{H}_{4}, 4-\mathrm{BrC}_{6} \mathrm{H}_{4}, 4-\mathrm{IC}_{6} \mathrm{H}_{4}, 4-\mathrm{MeC}_{6} \mathrm{H}_{4}, 4-\mathrm{MeO}$

Scheme 24. Three-component synthesis of fused pyrroles. ${ }^{96}$ 
Further, Jiang et al. developed related novel domino reactions for the synthesis of polyfunctionalized fused pyrroles $\mathbf{6 7}$ and $\mathbf{6 8}$ that allows the incorporation of nucleophilic moieties into the pyrrole C-4 position. This method is based on the microwave-promoted reaction between various $N$-substituted enaminones 63 and arylamines $\mathbf{8}$ with arylglyoxals $\mathbf{4}$ in the presence of acetic acid (Scheme 25). ${ }^{97}$

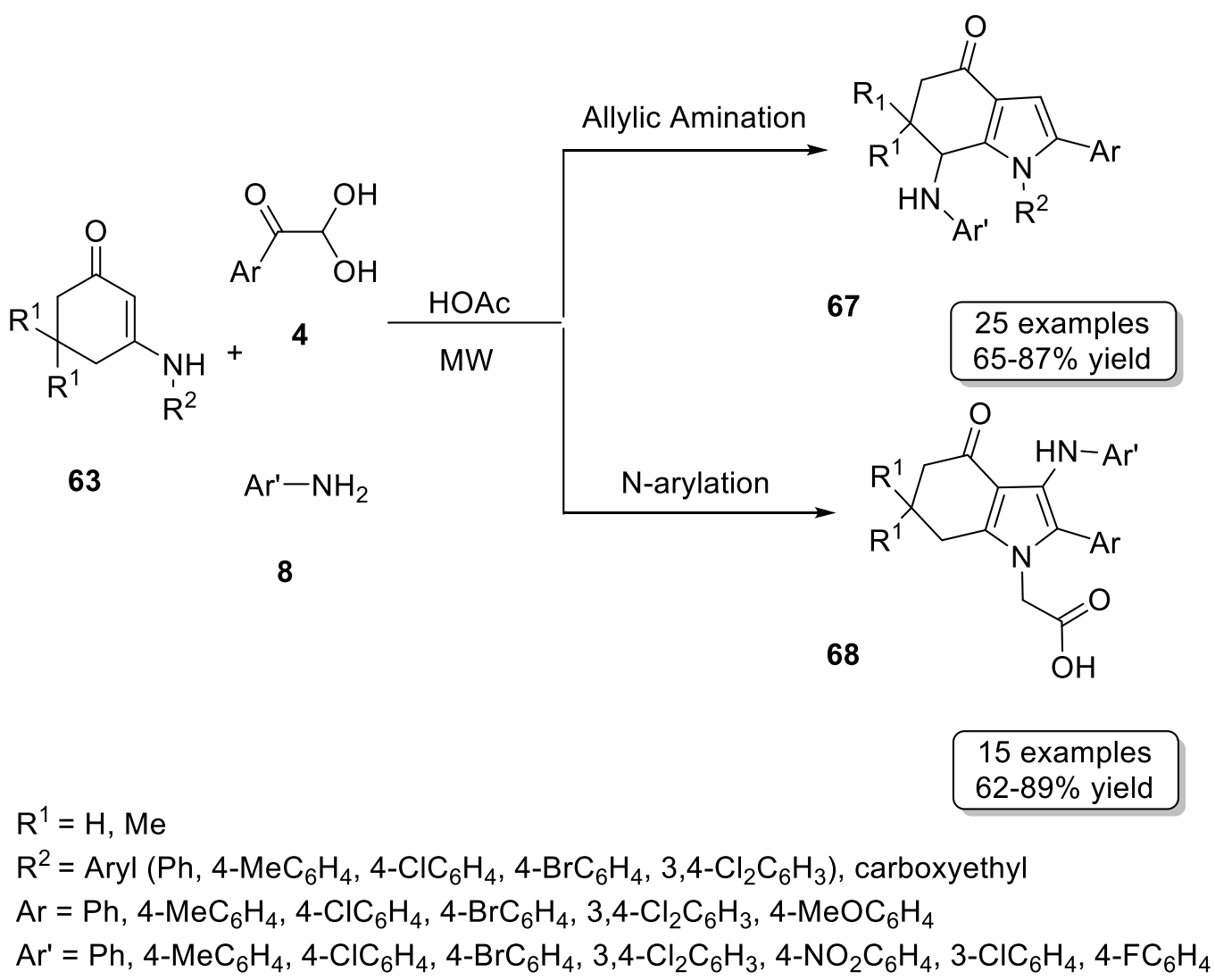

Scheme 25. Jiang's synthesis of polyfunctionalized fused pyrroles. ${ }^{97}$

Recently, Jiang's group has reported a series of three-component reaction between arylglyoxals 4 , enamonones 63, and an arylamine 8 to form 3-arylaminoindole derivatives 68 (Scheme 26). ${ }^{98}$

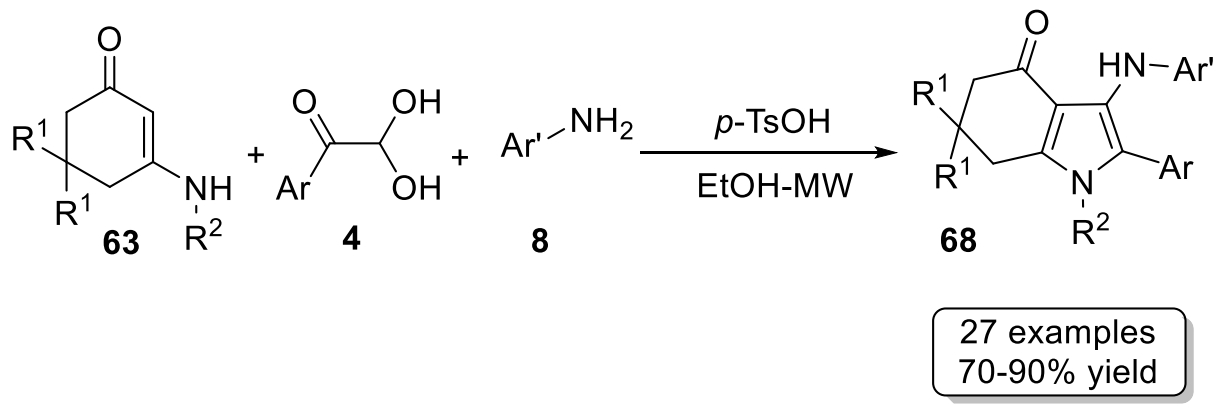

$$
\begin{aligned}
& \mathrm{Ar}=\mathrm{Ph}, 4-\mathrm{MeC}_{6} \mathrm{H}_{4}, 4-\mathrm{MeOC}_{6} \mathrm{H}_{4}, 4-\mathrm{FC}_{6} \mathrm{H}_{4}, 4-\mathrm{ClC}_{6} \mathrm{H}_{4}, 4-\mathrm{BrC}_{6} \mathrm{H}_{4} \\
& \mathrm{Ar}=\mathrm{Ph}, 4-\mathrm{MeC}_{6} \mathrm{H}_{4}, 3,4-\mathrm{Cl}_{2} \mathrm{C}_{6} \mathrm{H}_{3}, 4-\mathrm{FC}_{6} \mathrm{H}_{4}, 4-\mathrm{ClC}_{6} \mathrm{H}_{4}, 4-\mathrm{BrC}_{6} \mathrm{H}_{4}, 4-\mathrm{NO}_{2} \mathrm{C}_{6} \mathrm{H}_{4} \\
& \mathrm{R}^{1}=\mathrm{Me}, \mathrm{H} \\
& \mathrm{R}^{2}=\mathrm{Ph}, 4-\mathrm{MeC}_{6} \mathrm{H}_{4}, 4-\mathrm{FC}_{6} \mathrm{H}_{4}, 4-\mathrm{ClC}_{6} \mathrm{H}_{4}, 4-\mathrm{BrC}_{6} \mathrm{H}_{4}, 3,4-\mathrm{Cl}_{2} \mathrm{C}_{6} \mathrm{H}_{3}
\end{aligned}
$$

Scheme 26. Three-component dihydroindolone synthesis of Jiang et al. ${ }^{98}$ 
The pseudo-four-component reaction between one equivalent of enaminones 63 with arylglyoxals 4, phenylhydrazine 70, and dialkyl acetylenedicarboxylates 3 was reported by Tu et al. to afford multifunctionalized fused indole derivatives 71 selectively in good yields (Scheme 27). ${ }^{99}$ The mixture of enaminones 63 and arylglyoxals 4 in HOAC was firstly heated at $120{ }^{\circ} \mathrm{C}$ under microwave irradiation, and then phenylhydrazine $\mathbf{7 0}$ and dialkyl acetylenedicarboxylates $\mathbf{3}$ were added into the mixed system at $150{ }^{\circ} \mathrm{C}$, to form substituted pyrrole $\mathbf{7 1 .}$<smiles>CC1(C)CC(=O)C=C(N[Al])C1</smiles>

63

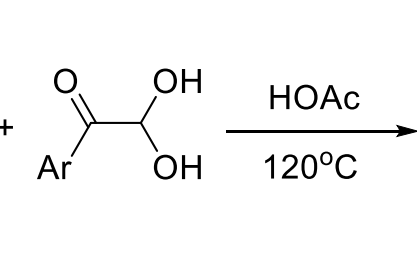

4

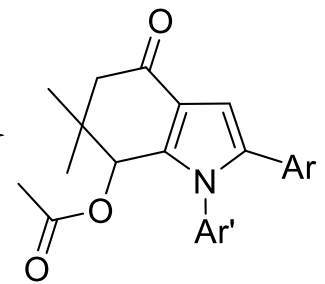

69

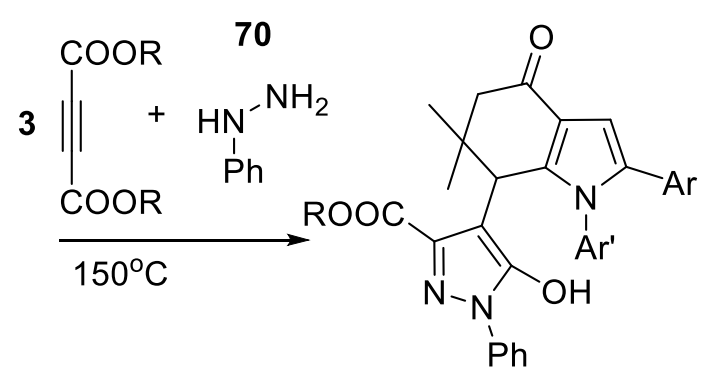

71

$$
\begin{aligned}
& \mathrm{Ar}=4-\mathrm{BrC}_{6} \mathrm{H}_{4}, 4-\mathrm{FC}_{6} \mathrm{H}_{4}, 4-\mathrm{ClC}_{6} \mathrm{H}_{4}, 4-\mathrm{MeC}_{6} \mathrm{H}_{4} \\
& \mathrm{Ar}=\mathrm{Ph}, 4-\mathrm{BrC}_{6} \mathrm{H}_{4}, 4-\mathrm{FC}_{6} \mathrm{H}_{4}, 4-\mathrm{ClC}_{6} \mathrm{H}_{4}, 4-\mathrm{MeC}_{6} \mathrm{H}_{4} \\
& \mathrm{R}=\mathrm{Me}, \mathrm{Et}
\end{aligned}
$$

Scheme 27. Tu's synthesis of polysubstituted tetrahydroindol-4-ones. ${ }^{99}$

The three-component reaction of enamonones 63, arylglyoxals 4, and indoles $\mathbf{2 5}$, in HOAc under microwave irradiation to give 72 and 73 in high yields has also been reported (Scheme 28). ${ }^{100}$

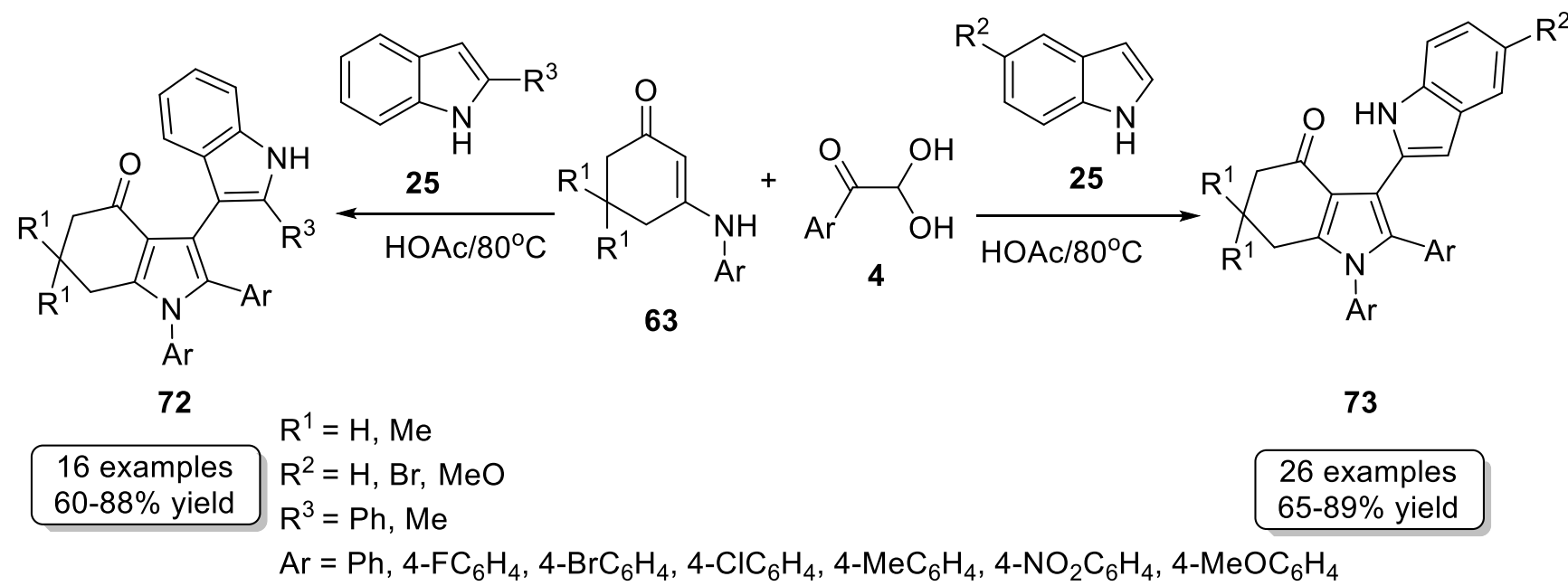

Scheme 28. Three-component synthesis of pyrroles starting from enaminones, arylglyoxals and indoles. ${ }^{100}$

Recently a new, green protocol was investigated for the construction of bis-isoxazolylamino dihydro- $1 \mathrm{H}$ indol-4(5H)-one derivatives $\mathbf{7 4}, \mathbf{7 8}$, and $\mathbf{8 0}$. The generality of the reaction was established by employing $\mathrm{N}$ isoxazolyl enaminone $\mathbf{7 6}$ with arylglyoxals 4 and a series of isoxazoles $\mathbf{7 5}, \mathbf{7 7}$, and $\mathbf{7 9}$ in the reaction process to produce the desired products in good to excellent yields in water and $\mathrm{AcOH}$ as catalyst under metal-free and refluxing conditions (Scheme 29). ${ }^{101}$ 

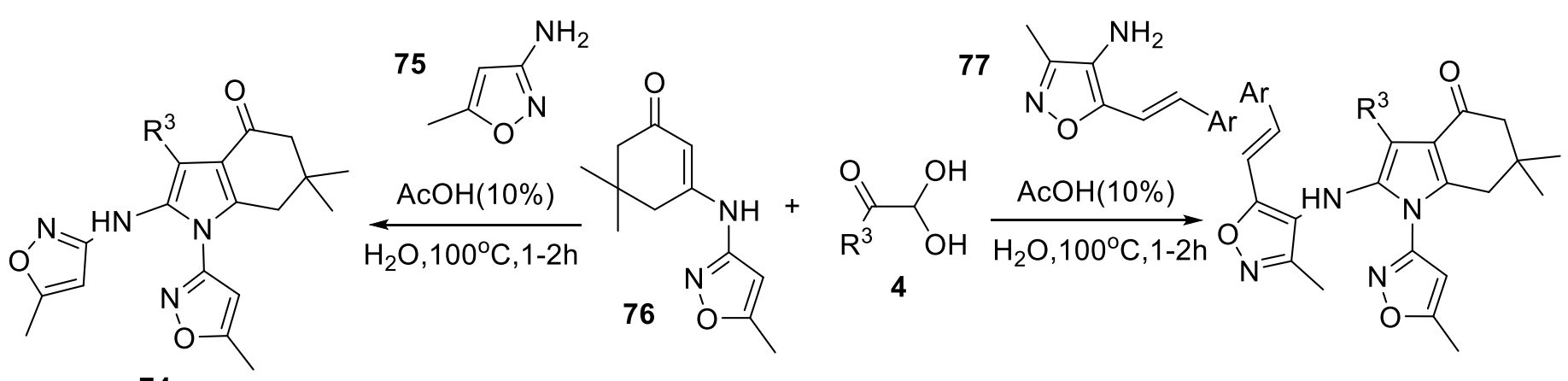

\section{4}

4 examples

$78-80 \%$ yield

$\mathrm{R}^{1}=\mathrm{Me}, \mathrm{Ph}$<smiles>[R]c1noc([R])c1N</smiles>

$\mathrm{AcOH}(10 \%)$

78

$$
78-80 \% \text { yield }
$$

$\mathrm{R}^{2}=\mathrm{Me}, \mathrm{Ph}, 4-\mathrm{ClC}_{6} \mathrm{H}_{4}$

$\mathrm{R}^{3}=\mathrm{Me}, \mathrm{Ar}\left(\mathrm{Ph}, 4-\mathrm{MeC}_{6} \mathrm{H}_{4}, 2-\mathrm{MeC}_{6} \mathrm{H}_{4}, 4-\mathrm{MeOC}_{6} \mathrm{H}_{4}, 4-\mathrm{ClC}_{6} \mathrm{H}_{4}, 2-\mathrm{ClC}_{6} \mathrm{H}_{4}, 4-\mathrm{BrC}_{6} \mathrm{H}_{4}, 4-\mathrm{NO}_{2} \mathrm{C}_{6} \mathrm{H}_{4}\right.$, $3-\mathrm{ClC}_{6} \mathrm{H}_{4}, 2-\mathrm{BrC}_{6} \mathrm{H}_{4}$ )

$\mathrm{Ar}=\mathrm{Ph}, 4-\mathrm{MeC}_{6} \mathrm{H}_{4}, 2-\mathrm{MeC}_{6} \mathrm{H}_{4}, 4-\mathrm{MeOC}_{6} \mathrm{H}_{4}, 4-\mathrm{ClC}_{6} \mathrm{H}_{4}, 2-\mathrm{ClC}_{6} \mathrm{H}_{4}, 2-\mathrm{MeOC}_{6} \mathrm{H}_{4}, 4-\mathrm{BrC}_{6} \mathrm{H}_{4}, 4-\mathrm{NO}_{2} \mathrm{C}_{6} \mathrm{H}_{4}$,

3- $\mathrm{ClC}_{6} \mathrm{H}_{4}, 4-\mathrm{BrC}_{6} \mathrm{H}_{4}, 2,4-\mathrm{Cl}_{2} \mathrm{C}_{6} \mathrm{H}_{3}, 4-\mathrm{NO}_{2} \mathrm{C}_{6} \mathrm{H}_{4}$, 2-FurylC ${ }_{6} \mathrm{H}_{4}$, 2-ThienylC ${ }_{6} \mathrm{H}_{4}, 3-\mathrm{PyC}_{6} \mathrm{H}_{4}$

Scheme 29. The synthesis of bis-isoxazolyl-1H-indol-4(5H)-one derivatives of Reddy and Kumar. ${ }^{101}$

Maity's group has reported the simple reaction of arylglyoxals 4 and enaminones 63 , for the synthesis of fused pyrrole derivatives $\mathbf{8 1}$ through microwave-assisted reactions under neutral conditions and in a nonnucleophilic solvent, without the use of any catalyst (Scheme 30). ${ }^{102}$

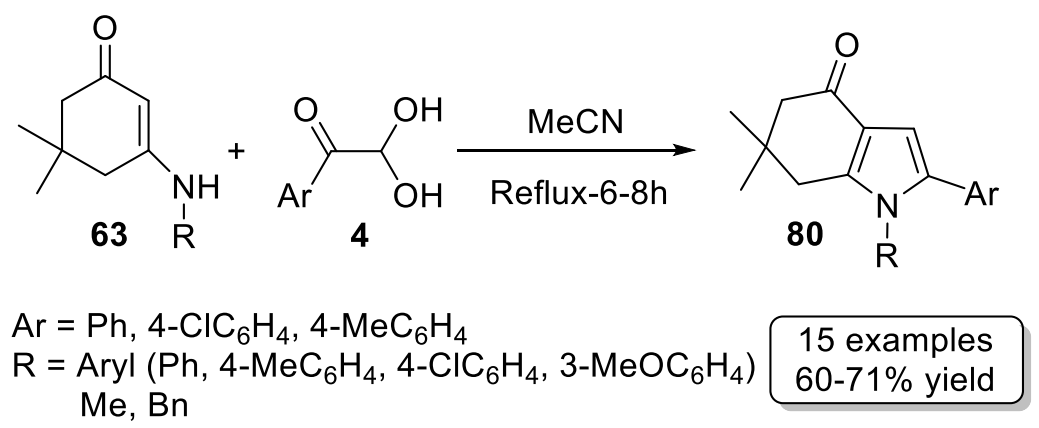

Scheme 30. Maity's synthesis of fused pyrroles. ${ }^{102}$ 
Continuing these investigations, Maity observed that heating a mixture of 3-arylaminocyclohex-2-enones 63 and arylglyoxals 4 at reflux in a non-nucleophilic solvent such as acetonitrile produced indol-4-ol derivatives 82 within 6-8 h in moderate-to-good yields. Surprisingly, completely different products were formed in a nucleophilic solvent such as ethanol; heating arylglyoxals 4 and enamine 63 in ethanol at reflux produced tetrahydroindol-4-one derivatives 81 in $6-8 \mathrm{~h}$ in good yields (Scheme 31). ${ }^{103}$ In this case a solvent molecule is incorporated into the product.

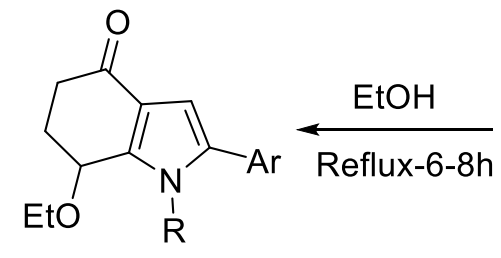

81<smiles>O=C(Br)C(O)O</smiles>

4<smiles>[R]NC1=CC(=O)CC[CH+]1</smiles>

63<smiles>[R]n1c([Al])cc2c(O)cccc21</smiles>

82

26 examples $40-60 \%$ yield

$$
\begin{aligned}
\mathrm{Ar}= & \mathrm{Ph}, 4-\mathrm{ClC}_{6} \mathrm{H}_{4}, 4-\mathrm{MeOC}_{6} \mathrm{H}_{4}, 4-\mathrm{NO}_{2} \mathrm{C}_{6} \mathrm{H}_{4}, 4-\mathrm{FC}_{6} \mathrm{H}_{4} \\
\mathrm{R}= & \text { Aryl }\left(\mathrm{Ph}, 4-\mathrm{MeC}_{6} \mathrm{H}_{4}, 3-\mathrm{ClC}_{6} \mathrm{H}_{4}, 3-\mathrm{MeOC}_{6} \mathrm{H}_{4}, 4-\mathrm{BrC}_{6} \mathrm{H}_{4}, 4-\mathrm{ClC}_{6} \mathrm{H}_{4}\right) \\
& \text { Cyclopropyl, Bn }
\end{aligned}
$$

Scheme 31. The synthesis of indole derivatives. ${ }^{103}$

Lin's group found that when anilines 8, arylglyoxals 4, and cyclic 1,3-dicarbonyl compounds 10 in a mixture of ethanol and water were subjected to microwave irradiation ( $\mathrm{MW}$ ), a regioselective three-component domino reaction proceeded to give 3-functionalized indole derivatives $\mathbf{8 3}$ (Scheme 32 ). ${ }^{104}$

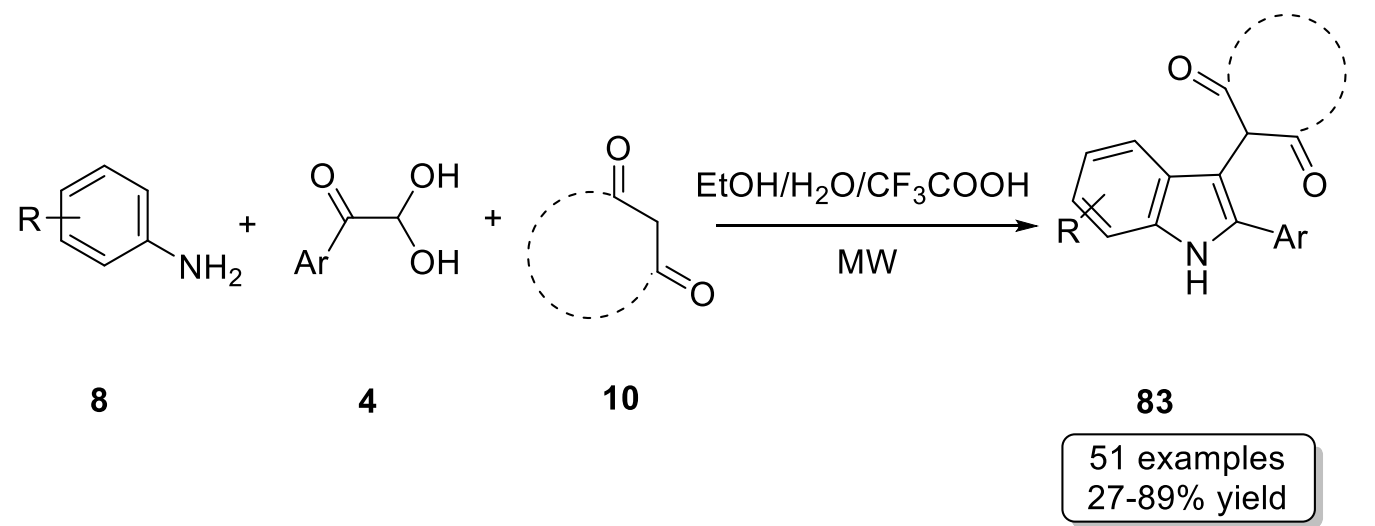

$\mathrm{R}=\mathrm{H}, 4-\mathrm{Me}, 4-\mathrm{Cl}, 4-\mathrm{Br}, 4-\mathrm{MeO}, 3-\mathrm{Me}, 4-\mathrm{F}, 3-\mathrm{Br}, 2,3-\mathrm{Me}_{2}$, 3-Cl, 3-Cl-4-Me, 3-Cl-4-F,
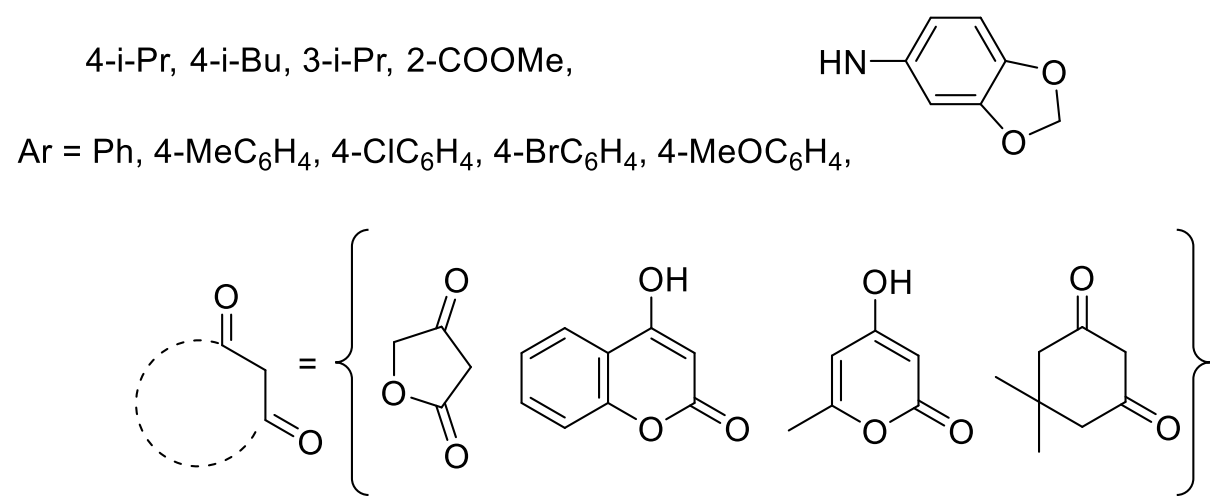

Scheme 32. Three-component synthesis of multifunctionalized indoles. ${ }^{104}$ 
Naidu has developed an efficient method for the synthesis of highly functionalized indoles 84 and bisindoles 85 by reductive alkylation of $\alpha$-keto imines, followed by cyclization process (Scheme 33). ${ }^{105}$ Similarly the one-pot reaction of aniline $\mathbf{8}$, arylglyoxals $\mathbf{4}$, and cyclic diketones 10/indoles $\mathbf{2 5}$ gave a large number of compounds (Scheme 33).

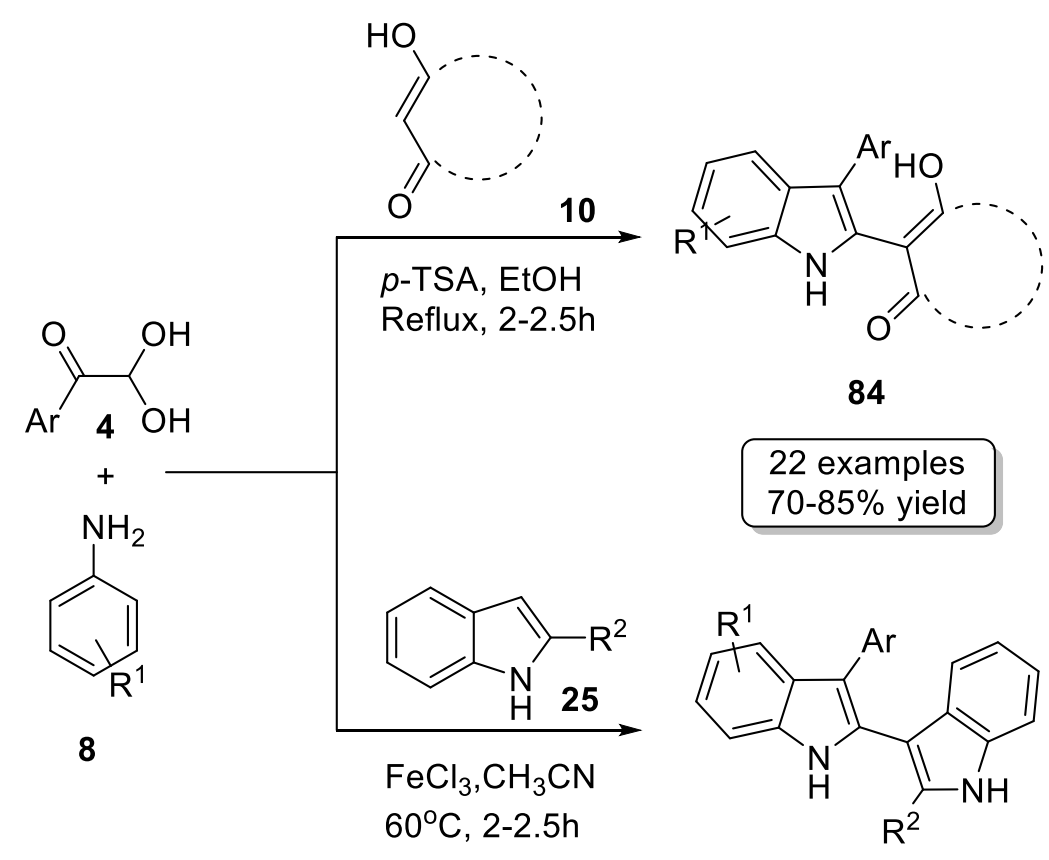

85

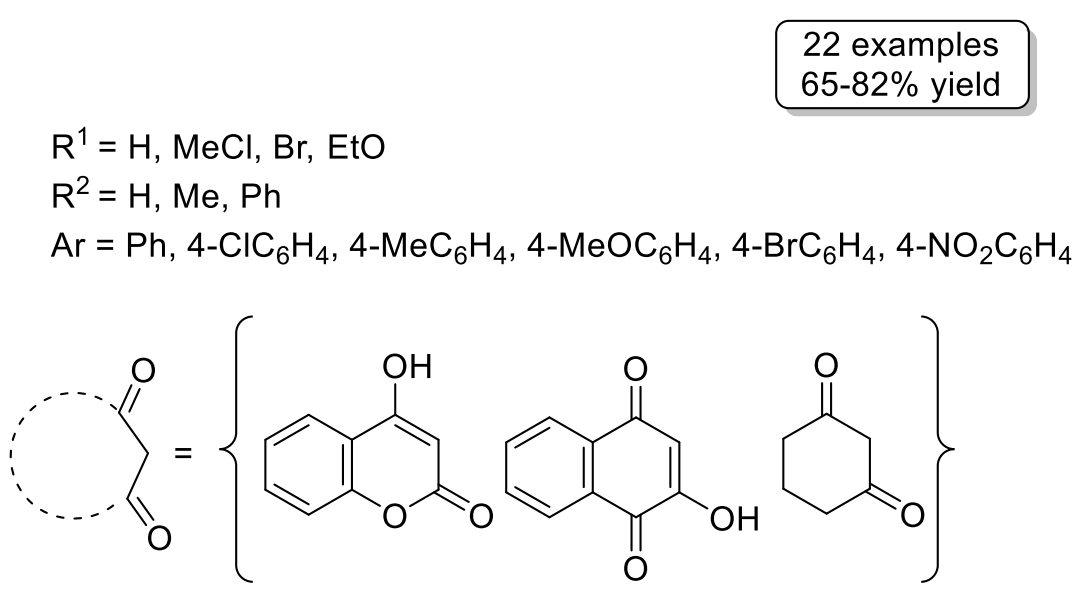

Scheme 33. Three-component syntheses of substituted indoles described by Naidu. ${ }^{105}$

\subsection{Synthesis of other fused pyrrole heterocycles}

In some very interesting reactions related to those of the previous subsection, but where an additional ring fused to the indole [hi] bonds is formed, Jiang and coworkers established a new three-component domino reaction for the synthesis of fused indole derivatives. The reaction is performed simply by mixing $N$-aryl enaminones and arylglyoxal $\mathbf{4}$ in acetic acid as solvent and applying microwave irradiation. Under such conditions, 1,2-diaryl dihydroindolones are formed, but with the aminoacid-derived enaminones 86 the tricyclic 1,4-oxazine-fused indole derivatives 87 are formed (Scheme 34). ${ }^{106}$ 
<smiles>[R]C(NC1=CC(=O)CC([R])([R])C1)C(=O)O</smiles>

86<smiles>CC(C)CC(=O)OC(O)C(=O)Br</smiles>

4<smiles>[R]C1C(=O)OC2([R])c3c(cc(Br)n31)C(=O)CC2([R])[R]</smiles>

87

$$
\begin{aligned}
\mathrm{R}^{1}= & \mathrm{Me} \\
\mathrm{R}^{2}= & \mathrm{H}, \mathrm{Me}, \mathrm{Et} \\
\mathrm{Ar}= & \mathrm{Ph}, 4-\mathrm{FC}_{6} \mathrm{H}_{4}, 4-\mathrm{ClC}_{6} \mathrm{H}_{4}, 3,4-\mathrm{Cl}_{2} \mathrm{C}_{6} \mathrm{H}_{3}, 3-\mathrm{MeOC}_{6} \mathrm{H}_{4}, 4-\mathrm{MeOC}_{6} \mathrm{H}_{4}, \\
& 4-\mathrm{BrC}_{6} \mathrm{H}_{4}, 4-\mathrm{MeC}_{6} \mathrm{H}_{4}, 3,4-(\mathrm{MeO})_{2} \mathrm{C}_{6} \mathrm{H}_{3}
\end{aligned}
$$

Scheme 34. Synthesis of oxazino-indoles. ${ }^{106}$

Yang, Zhong and coworkers described a method for the synthesis of polysubstituted fused pyrroles $\mathbf{8 8}$ and 90 in moderate to high yields (Scheme 35). ${ }^{107}$ The synthetic strategy was based on a one-pot procedure involving condensation of 3-aminocoumarins 89 and arylglyoxasl 4 in refluxing ethanol in the presence of catalytic $p$-TSA to give $\mathbf{8 8}$, or in toluene to give $\mathbf{9 0}$.

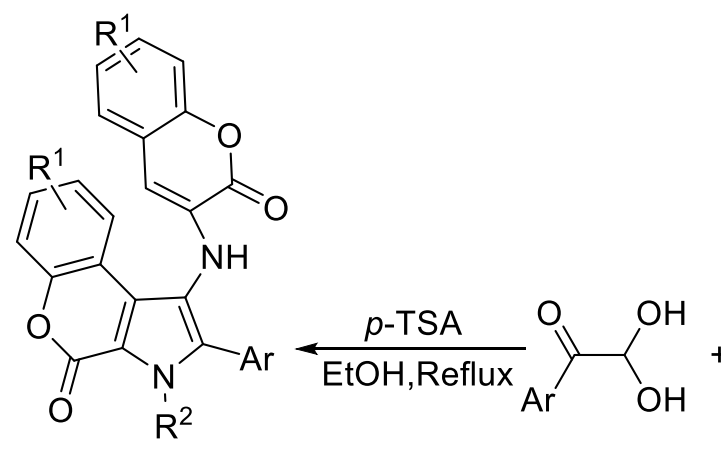

88

4

13 examples $75-92 \%$ yield

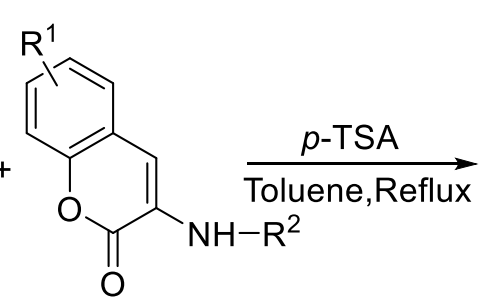

89

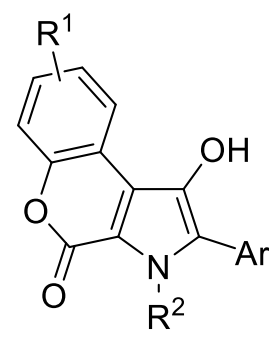

90

16 examples $54-78 \%$ yield

$\mathrm{R}^{1}=\mathrm{H}, 6-\mathrm{Me}, 6-\mathrm{Cl}, 7-\mathrm{MeO}$

$\mathrm{R}^{2}=\mathrm{H}, \mathrm{Me}$, Allyl, 4-BrBn

$\mathrm{Ar}=\mathrm{Ph}, 4-\mathrm{ClC}_{6} \mathrm{H}_{4}, 3-\mathrm{ClC}_{6} \mathrm{H}_{4}, 2-\mathrm{ClC}_{6} \mathrm{H}_{4}, 4-\mathrm{NO}_{2} \mathrm{C}_{6} \mathrm{H}_{4}, 4-\mathrm{BrC}_{6} \mathrm{H}_{4}, 4-\mathrm{MeC}_{6} \mathrm{H}_{4}, 2-\mathrm{MeC}_{6} \mathrm{H}_{4}, 4-\mathrm{MeOC}_{6} \mathrm{H}_{4}$

Scheme 35. Zhong's synthesis of polysubstituted pyrroles. ${ }^{107}$

In another study by this group, the synthesis of polyfunctionalized fused pyrroles $\mathbf{9 2}$ was accomplished by intermolecular cycloaddition of arylglyoxals $\mathbf{4}$ with 4-aminocoumarins $\mathbf{9 1}$ and cyclic diketones $\mathbf{1 0}$ as the key step using readily available starting materials. Various arylglyoxals $\mathbf{4}$ were found to be compatible in this reaction and their electronic nature and substitution pattern had little influence on the reaction efficiency; the corresponding products 92 were formed in moderate to good yields (Scheme 36). ${ }^{108}$ 


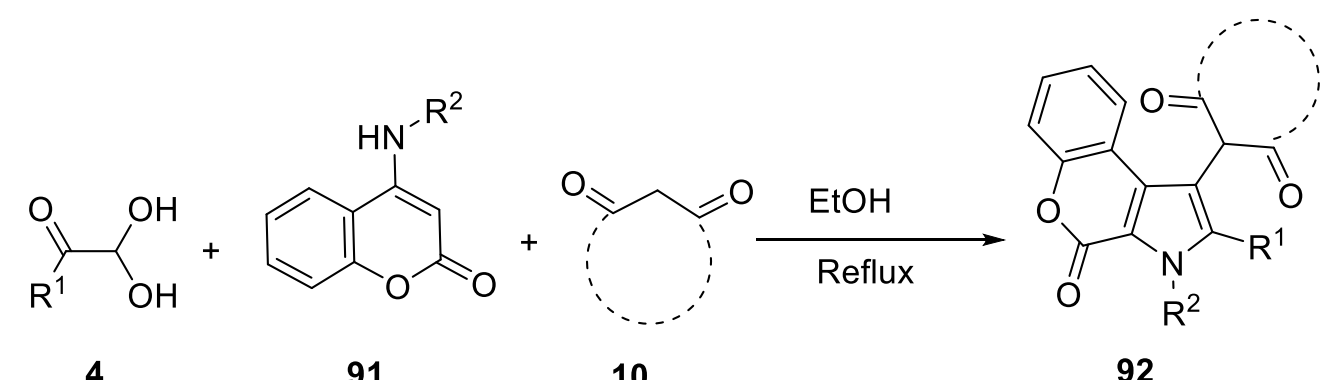

$$
\begin{aligned}
& \mathrm{R}^{1}=\mathrm{H}, \mathrm{n}-\mathrm{Bu}, \mathrm{Ph}, \mathrm{HOCH}_{2} \mathrm{CH}_{2} \mathrm{C}_{6} \mathrm{H}_{4} \\
& \mathrm{R}^{2}=\mathrm{Me}
\end{aligned}
$$

$\operatorname{Ar}\left(\mathrm{Ph}, 4-\mathrm{ClC}_{6} \mathrm{H}_{4}, 3-\mathrm{ClC}_{6} \mathrm{H}_{4}, 2-\mathrm{ClC}_{6} \mathrm{H}_{4}, 4-\mathrm{NO}_{2} \mathrm{C}_{6} \mathrm{H}_{4}, 4-\mathrm{BrC}_{6} \mathrm{H}_{4}, 4-\mathrm{MeC}_{6} \mathrm{H}_{4}, 2-\mathrm{MeC}_{6} \mathrm{H}_{4}\right.$, $4-\mathrm{MeOC}_{6} \mathrm{H}_{4}, 3-\mathrm{MeOC}_{6} \mathrm{H}_{4}, 4-\mathrm{OHC}_{6} \mathrm{H}_{4}, 4-\mathrm{FC}_{6} \mathrm{H}_{4}$, ( $\mathrm{S}$ )<smiles>Cc1ccc2c(c1)OCO2</smiles>

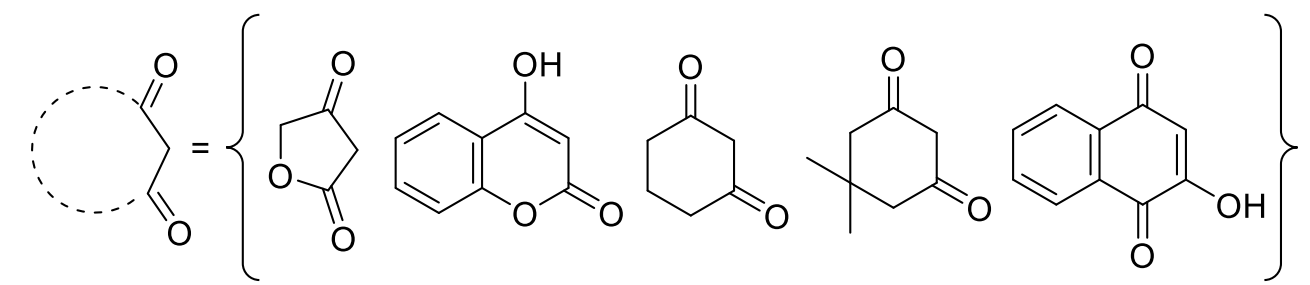

Scheme 36. Yang's three-component synthesis of polyfunctionalized fused pyrroles. ${ }^{108}$

Su et al. studied the three-component reactions of 4-aminocoumarins 91, arylglyoxals 4, and anilines 8 in toluene at reflux using $\mathrm{KHSO}_{4}$ as a catalyst, to give the products $\mathbf{9 3}$ in moderate to excellent yields (Scheme 37). ${ }^{109}$

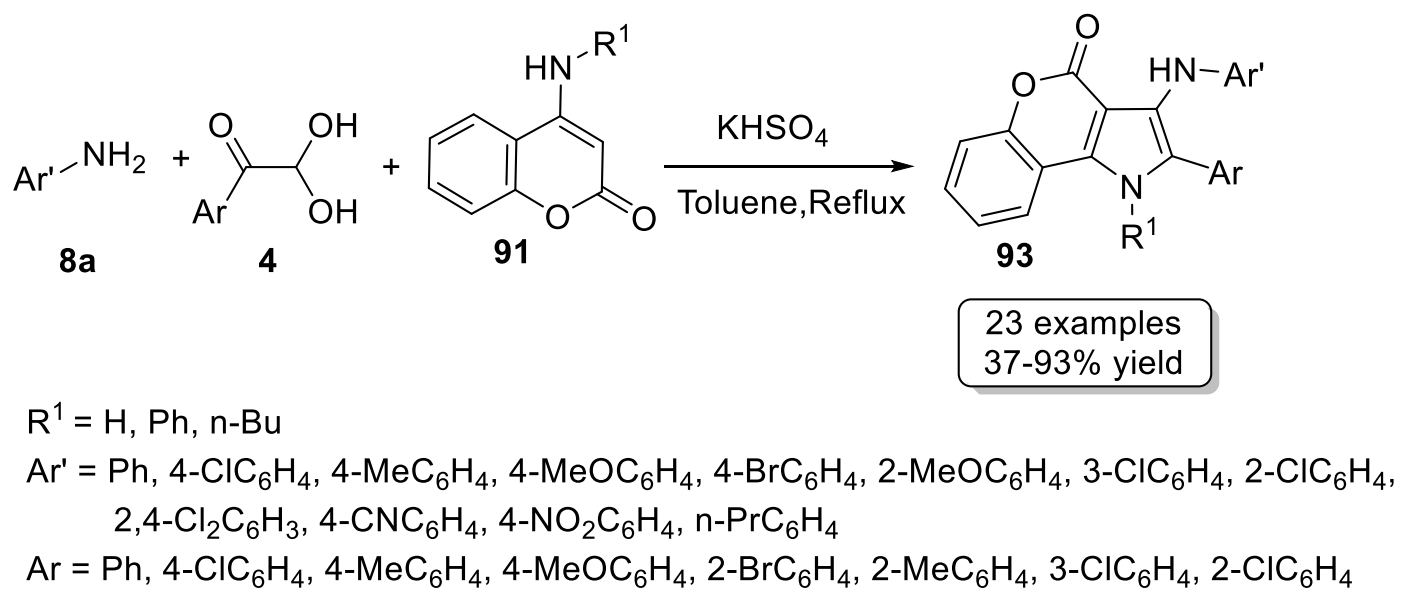

Scheme 37. Synthesis of fused pyrroles from 4-aminocoumarins, arylglyoxals and anilines. ${ }^{109}$

Javahershenas and Khalafy reported a new method for the synthesis of pyrrolo[2,3-d]pyrimidine derivatives 95 through the one-pot, the three-component reaction of 4-hydroxycoumarin 34, arylglyoxals 4 and 6-aminouracil or 1,3-dimethyl-6-aminouracil 94 catalyzed by L-proline (Scheme 38). ${ }^{110}$ 


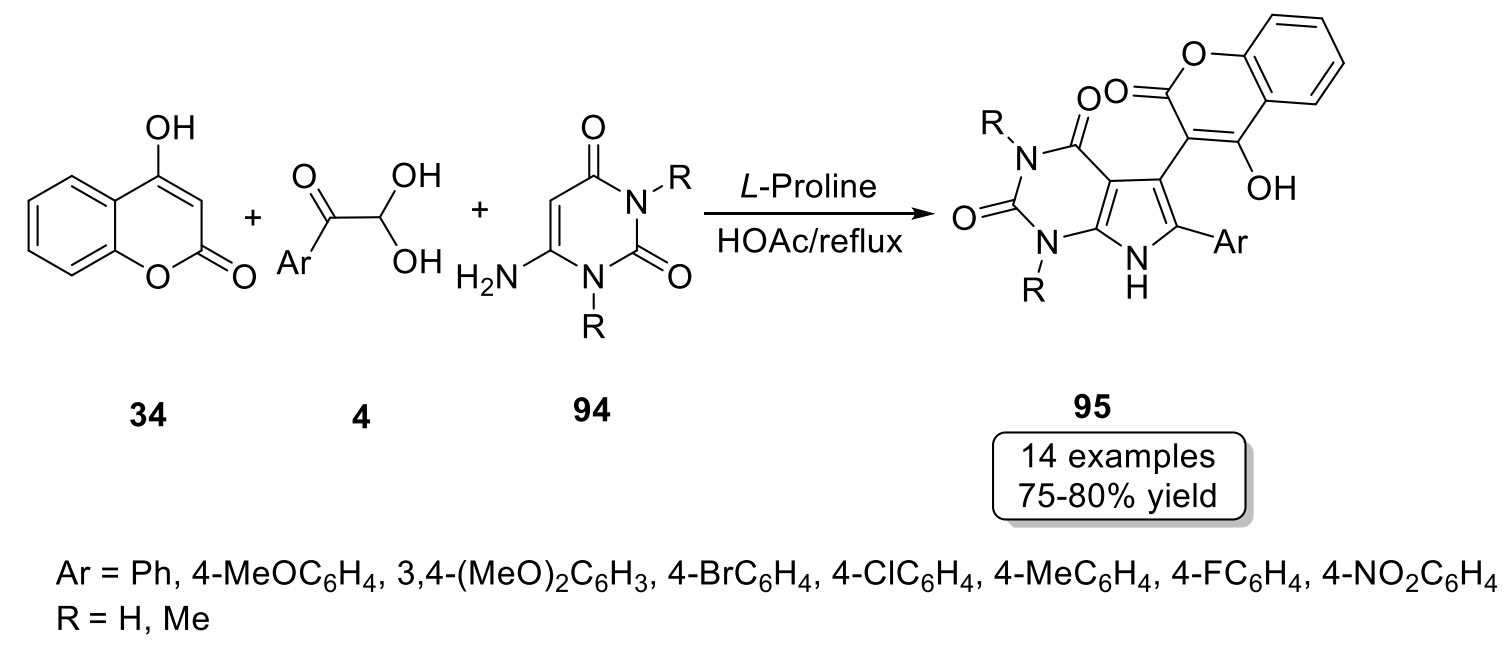

Scheme 38. Javahershenas and Khalafy's three-component synthesis of polyfunctionalized fused pyrroles. ${ }^{110}$

In another study, this group reported an efficient procedure for the reaction of arylglyoxals 4 with 6 amino-1,3-dimethyluracil 94 and barbituric acid derivatives 39 in the presence of TBAB (5 mol\%) in ethanol at $50{ }^{\circ} \mathrm{C}$, affording polyfunctionalized pyrrolo[2,3-d]pyrimidine derivatives 96 in high yields (Scheme 39). ${ }^{111}$<smiles>[X][CH2+]C(O)C(=O)[Te]</smiles>

4<smiles>Cn1c(N)cc(=O)n(C)c1=O</smiles>

93<smiles>[R]N1C(=O)CC(=O)N([R])C1=[V]</smiles>

39<smiles>[Y]C1N([R])C(=O)C(c2c([Al])[nH]c3c2c(=O)n(C)c(=O)n3C)C(=O)N1[R]</smiles>

96

14 examples $75-80 \%$ yield

$\mathrm{R}=\mathrm{H}, \mathrm{Me}$

$Y=O, S$

Scheme 39. Three-component pyrrolopyrimidine synthesis developed by Javahershenas and Khalafy. ${ }^{111}$

Recently, the synthesis of polyfunctionalized pyrrolo[2,3-d]pyrimidine derivatives was reported in a review. $^{70}$

Chen and coworkers have reported the multicomponent synthesis of N-bridgehead-fused pyrroles 98 and 99 by reaction of arylglyoxals 4, cyclohexane-1,3-diones 31, and heterocyclic ketene aminals (HKA) 97 under two different reflux conditions in high yield (Scheme 40). ${ }^{112}$

In further work of Chen et al., the reaction between one equivalent of an HKA 97 with arylglyoxals $\mathbf{4}$ and 1,3-diphenylpropane-1,3-dione $\mathbf{1 0 0}$ is reported to proceed selectively, providing multifunctionalized fused pyrrole derivatives 101 in high yields, as shown in Scheme $41 .^{113}$ 
<smiles>[R]C1([R])CC(=O)C(=C2C(C(=O)[Al])=C3NCCCN3C2(O)[Al])C(=O)C1</smiles>

98

Thermodynamic Control
$\frac{\mathrm{H}_{2} \mathrm{O} / \text { EtOH }(3: 1)}{\text { Reflux, } 6 \mathrm{~h}}$

Reflux, 6h

examples $8-90 \%$ yield
$\mathrm{R}=\mathrm{H}, \mathrm{Me}$

$\mathrm{Ar}=\mathrm{Ph}, 4-\mathrm{FC}_{6} \mathrm{H}_{4}$

$\mathrm{Ar}^{\prime}=\mathrm{Ph}, 4-\mathrm{FC}_{6} \mathrm{H}_{4}, 3-\mathrm{ClC}_{6} \mathrm{H}_{4}, 3-\mathrm{FC}_{6} \mathrm{H}_{4}, 4-\mathrm{ClC}_{6} \mathrm{H}_{4}, 4-\mathrm{MeC}_{6} \mathrm{H}_{4}, 4-\mathrm{MeOC}_{6} \mathrm{H}_{4}$<smiles>[R]C1([R])CC(=O)C(c2c(C(=O)[Al])c3n(c2Br)CCCN3)=C(O)C1</smiles>

99

Kinetic Control

12 examples $81-95 \%$ yield

Scheme 40. Chen's synthesis of N-bridgehead fused pyrroles. ${ }^{112}$<smiles>O=C(Br)C(O)O</smiles>

4<smiles>O=C(Br)/C=C1\CCCCN1</smiles>

97<smiles>O=C(CC(=O)c1ccccc1)c1ccccc1</smiles>

100<smiles>O=C(O)CCCCCC(=O)O</smiles><smiles>CC1CNCN(CCBr)C1</smiles>

$$
\begin{aligned}
& \mathrm{n}=1,2 \\
& \mathrm{Ar}=\mathrm{Ph}, 4-\mathrm{FC}_{6} \mathrm{H}_{4}, 4-\mathrm{MeOC}_{6} \mathrm{H}_{4} \\
& \mathrm{Ar}
\end{aligned}
$$

Scheme 41. Three-component synthesis of further fused pyrroles. ${ }^{113}$

In other research, Chen developed a method to synthesize pyrrolo[1,2-a]pyrimidine and pyrrolo[1,2a][1,3]diazepine rings 102 in good to excellent yields by simply heating the HKA 97, indoles 25, and arylglyoxasl 4, catalyzed by HOAc in ethanol under reflux. (Scheme 42). ${ }^{114}$<smiles>O=C([Al])C(O)O</smiles>

4<smiles>O=C(Br)C=C1NCCCN1</smiles>

97<smiles>[R]c1cc2c([nH]1)=C[C+]=CC=2</smiles>

25

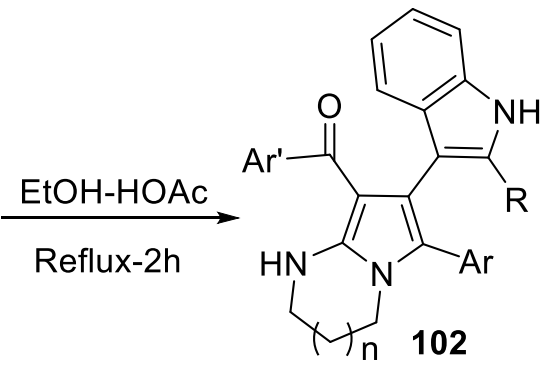<smiles>[R]c1[nH]c2ccccc2c1-c1c(C(=O)[Al])c2n(c1[R])C([Y6])CN2</smiles>

26 examples $72-95 \%$ yield

$\mathrm{R}=\mathrm{H}, \mathrm{Me}, \mathrm{Ph}$

$\mathrm{Ar}=\mathrm{Ph}, 4-\mathrm{FC}_{6} \mathrm{H}_{4}$

$A r^{\prime}=\mathrm{Ph}, 4-\mathrm{FC}_{6} \mathrm{H}_{4}, 3-\mathrm{FC}_{6} \mathrm{H}_{4}, 4-\mathrm{ClC}_{6} \mathrm{H}_{4}, 3-\mathrm{ClC}_{6} \mathrm{H}_{4}, 4-\mathrm{MeC}_{6} \mathrm{H}_{4}$

$\mathrm{n}=1,2$

Scheme 42. A three-component synthesis of polyfunctionalized fused pyrroles by Chen et al. ${ }^{114}$ 
Jiang et al. observed that, considering the presence of two carbonyl groups in arylglyoxals, these species sometimes react only at the aldehyde functionality, while in other reactions both the functional groups are involved in the formation of heterocycles. Therefore they studied the outcome of the reaction of arylglyoxals 4 with 5-aminopyrazoles 103 in a 1:2 molar ratio; dihydropyrrolopyrazoles 104 were formed in DMF using $p$-TSA as a promoter under microwave irradiation conditions (Scheme 43). ${ }^{115}$
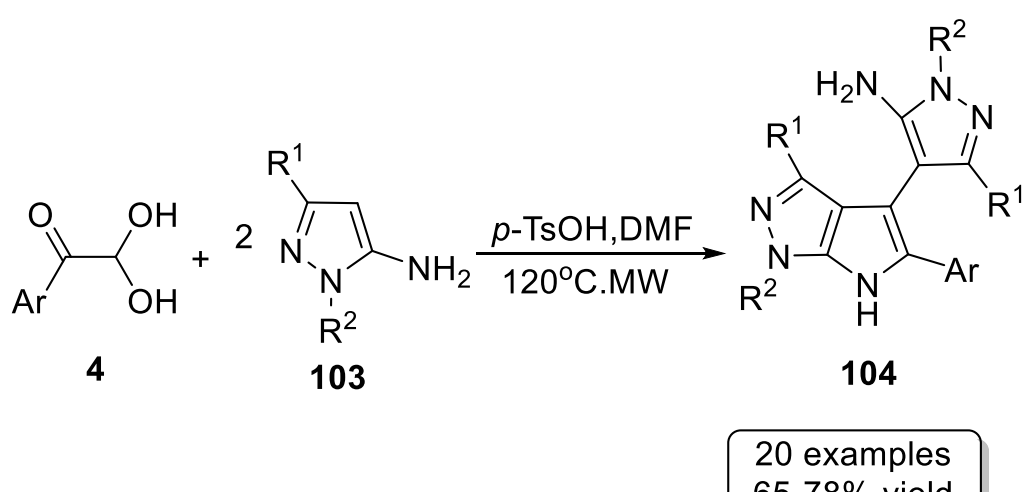

$$
\begin{aligned}
& \mathrm{Ar}=\mathrm{Ph}, 4-\mathrm{FC}_{6} \mathrm{H}_{4}, 4-\mathrm{ClC}_{6} \mathrm{H}_{4}, 4-\mathrm{NO}_{2} \mathrm{C}_{6} \mathrm{H}_{4}, 4-\mathrm{MeC}_{6} \mathrm{H}_{4}, 4-\mathrm{BrC}_{6} \mathrm{H}_{4} \\
& \mathrm{R}^{1}=\mathrm{Me}, \text { Cyclopropyl, 2-Thienyl } \\
& \mathrm{R}^{2}=\mathrm{Me}, \text { Aryl }\left(\mathrm{Ph}, 4-\mathrm{MeC}_{6} \mathrm{H}_{4}\right)
\end{aligned}
$$

Scheme 43. One-pot synthesis of substituted pyrrolo-pyrazoles. ${ }^{115}$

\section{Conclusions}

Pyrrole synthesis has attracted the attention of synthetic researchers because of their promising properties and applications in medicinal and natural products chemistry. Arylglyoxals, with two active functional groups, are a unique synthon in multicomponent reactions (MCRs) leading to substituted pyrroles and related compounds. This review has detailed how arylglyoxals can play an important and key role for the rapid assembly of complex molecules proven to exhibit diverse biological activities, and are extremely useful synthons in the total synthesis of natural products. In addition, this review covers more than ninety percent of the protocols published in the last two decades for the synthesis of pyrrole based compounds using arylglyoxals via multicomponent reactions.

\section{Acknowledgement}

The authors are grateful for support of this work from the University of Urmia.

\section{References}

1. Jones, R.A.; Bean, G.P. The Chemistry of Pyrroles, Academic Press: London, 1977; Vol 34.

2. Gossauer, A. In Methoden der Organichen Chemie (Houben-Weyl), Hetarene I, Teil 1 Pyrrole, Georg Thieme Verlag: Stuttgart, New York, 1994; p 556.

3. Gribble, G.W. In Comprehensive Heterocyclic Chemistry II, Katritzky, A.R.; Rees C.W.; Scriven, E.F.V. Eds., Pergamon: London, 1996; Vol. 2, Ch. 4. 
4. Walsh, C.T.; Garneau-Tsodikova, S.; Howard-Jones, A.R. Nat. Prod. Rep. 2006, 23, 517. https://doi.org/10.1039/B605245M

5. Forte, B.; Malgesini, B.; Piutti, C.; Quartieri, F.; Scolaro A.; Papeo, G. Mar. Drugs, 2009, 7, 705. https://doi.org/10.3390/md7040705

6. Estévez, V.; Villacampa, M.; Menéndez, J.C. Chem. Soc. Rev. 2014, 43, 4633. https://doi.org/10.1039/C3CS60015G

7. Jones, R.A. Ed. Pyrroles, The synthesis and the physical and chemical aspects of the pyrrole ring, Wiley-Interscience: New York, 1990.

8. Gholap, S.S. Eur. J. Med. Chem. 2015, 110, 13. https://doi.org/10.1016/i.ejmech.2015.12.017

9. Estevez, V.; Villacampa, M.; Menendez, J.C. Chem. Soc. Rev. 2010, 39, 4402. https://doi.org/10.1039/B917644F

10. Fernandes, E.; Costa, D.; Toste, S.A.; Lima, J.L.; Reis, S. Free Radic. Biol. Med. 2004, 37, 1895. https://doi.org/10.1016/j.freeradbiomed.2004.09.001

11. Biava, M.; Porretta, G.C.; Poce, G.; De Logu, A.; Meleddu, R.; De Rossi, E.; Manetti, F.; Botta, M. Eur. J. Med. Chem. 2009, 44, 4734. https://doi.org/10.1016/j.ejmech.2009.06.005

12. Biava, M.; Porretta, G.C.; Poce, G.; Supino, S.; Deidda, D.; Pompei, R.; Molicotti, P.; Manetti, F.; Botta, M. J. Med. Chem. 2006, 49, 4946.

https://doi.org/10.1021/jm0602662

13. Ye, Z.; Shi, L.; Shao, X.; Xu, X.; Xu, Z.; Li, Z. J. Agric. Food Chem. 2013, 61, 312. https://doi.org/10.1021/if3044132

14. Ghose, A.K.; Vellarkad, N.V.; Wendoloski, J.J. J. Comb. Chem. 1999, 1, 55. https://doi.org/10.1021/cc9800071

15. Ma, Zh.; Ma, Z.; Zhang, D. Molecules 2018, 23, 2666. https://doi.org/10.3390/molecules23102666.

16. Buchardt, O.; Bove, J. J. Electrochem. Soc., 1977, 124, $235 \mathrm{C}$. https://doi.org/10.1149/1.2133506

17. Badgujar, D.M.; Talawar, M.B.; Asthana, S.N.; Mahulikar, P.P. J. Hazardous Mater. 2008, $151,289$. https://doi.org/10.1016/j.jhazmat.2007.10.039

18. Dastan, A.; Kulkarni, A.; Torok, B. Green Chem. 2012, 14, 17. https://doi.org/10.1039/C2GC16637B

19. Lee, H.; Lee, J.; Lee, S. Bioorg. Med. Chem. Lett. 2001, 11, 3069. https://doi.org/10.1016/S0960-894X(01)00624-2

20. Mohamed, M.S.; Kamel, R.; Fatahala, S.S. Eur. J. Med. Chem. 2011, 46, 3022. https://doi.org/10.1016/j.ejmech.2011.04.034

21. Jana, G.H.; Jain, S.; Arora, S.K. Bioorg. Med. Chem. Lett. 2005, 15, 3592. https://doi.org/10.1016/i.bmcl.2005.05.080

22. Idhayadhulla, A.; Kumar, R.S.; Nasser, A.J.A. J. Mex. Chem. Soc. 2011, 55, 218. https://doi.org/10.29356/imcs.v55i4.803

23. Massa, S.; Artico, M.; Corelli, F.; Mai, A.; Di Santo, R.; Cortes, S.; Marongiu, M.E.; Pani, A.; La Colla, P. J. Med. Chem. 1990, 33, 2845.

https://doi.org/10.1021/jm00172a026 
24. Williamson, N.R.; Simonsen, H.T.; Ahmed, R.A.; Goldet, G.; Slater, H.; Woodley, L.; Leeper, F.J.; Salmond, G.P. Mol. Microbiol. 2005, 56, 971.

https://doi.org/10.1111/i.1365-2958.2005.04602.x

25. Daidone, G.; Maggio, B.; Schillaci, D. Pharmazie 1990, 45, 441.

26. Melagraki, G.; Afantitis, A., Igglessi-Markopoulou, O.; Detsi, A.; Koufaki, M.; Kontogiorgis, C.; Hadjipavlou-Litina, D.J. Eur. J. Med. Chem. 2009, 44, 3020.

https://doi.org 10.1016/j.ejmech.2008.12.027

27. Lee, H.; Lee, J.; Lee, S.K.; Shin, Y.; Jung, W.; Kim, J.H.; Park, K.; Kim, K.; Cho, H.S.; Ro, S. Bioorg. Med. Chem. Lett. 2001, 11, 3069.

https://doi.org/10.1016/s0960-894x(01)00624-2

28. Paludetto, M.N.; Bijani, C.; Puisset, F.; Bernardes-Génisson, V.; Arellano, C.; Robert, A. J. Med. Chem. 2018, 61, 7849.

https://doi.org/10.1021/acs.jmedchem.8b00812

29. Williamson, N.R.; Fineran, P.C.; Gristwood, T.; Chawrai, S.R.; Leeper, F.J.; Salmond, G.P.C. Future Microbiol. 2007, 2, 605.

https://doi.org/10.2217/17460913.2.6.605

30. Jonas, R.; Klockow, M.; Lues, I.; Pruecher, H.; Schliep, H.J.; Wurziger, H. Eur. J. Med. Chem. 1993, 28, 129.

https://doi.org/10.1016/0223-5234(93)90005-Y

31. Basit, F.; Cristofanon, S.; Fulda, S. Cell Death Differ. 2013, 29, 1161.

https://doi.org/10.1038/cdd.2013.45

32. El-Gaby, M.S.A.; Gaber, A.M.; Atalla, A.A.; Abd Al-Wahab, K.A. I/ Farmaco 2002, 57, 613.

https://doi.org/10.1016/S0014-827X(01)01178-8

33. Lee, H.; Lee, J.; Lee, S.; Shin, Y.; Jung, W.; Kim, J.-H.; Park, K.; Kim, K.; Cho, H.S.; Ro, S. Bioorg. Med. Chem. Lett. 2001, 11, 3069.

https://doi.org/10.1016/S0960-894X(01)00624-2

34. Ragno, R.; Coluccia, A.; Regina, G.L.; Martino, G.D.; Piscitelli, F.; Lavecchia, A.; Novellino, E.; Bergamini, A.; Ciaprini, C.; Sinistro, A.; Maga, G.; Crespan, E.; Artico, M.; Silvestri, R. J. Med. Chem. 2006, 49, 3172.

https://doi.org/10.1021/im0512490

35. Kaiser, D.G.; Glenn, E.M. J. Pharm. Sci. 1972, 61, 1908.

https://doi.org/10.1002/jps.2600611205

36. Gordee, R.S.; Matthews, T.R. Appl. Microbiol. 1969, 17, 690.

37. Di Santo, R.; Tafi, A.; Costi, R.; Botta, N.; Artico, M.; Corelli, F.; Forte, M.; Caporuscio, F.; Angiolella, L.; Palamara, A.T. J. Med. Chem. 2005, 48, 5140.

https://doi.org 10.1021/im048997u

38. Hyneck, M.L.; Smitch, P.C.; Munafo, A.; Mcdonagh, A.F.; Benet, L.Z. Pharmacol. Ther. 1988, $44,107$.

39. Wilkerson, W.W.; Copel, R.A.; Covington, M.; Trzaskos, J.M. J. Med. Chem. 1995, 38, 3895. https://doi.org/10.1021/jm00020a002

40. Battilocchio, C.; Poce, G.; Alfonso, S.; Porretta, G.C.; Consalvi, S.; Sautebin, L.; Pace, S.; Rossi, A.; Ghelardini, C.; Mannelli, L.D.C.; Schenone, S.; Giordani, A.; Francesco, L.D.; Patrignani, P.; Biava, M. Bioorg. Med. Chem. 2013, 21, 3695.

https://doi.org/10.1016/j.bmc.2013.04.031 
41. Danchev, N.; Bijev, A.; Yaneva, D.; Vladimirova, S.; Nikolova, I. Arch. Pharm. (Weinheim) 2006, 339, 670.

https://doi.org/10.1002/ardp.200600116

42. Jiang, S.B.; Lu, H.; Liu, S.W.; Zhao, Q.; He, Y.X.; Debnath, A.K. Antimicrob. Agents Chemother. 2004, $48,4349$.

https://doi.org/10.1128/AAC.48.11.4349-4359.2004

43. Okanya, P.W.; Mohr, K.I.; Gerth, K.; Jansen, R.; Müller, R. J. Nat. Prod. 2011, 74, 603. https://doi.org 10.1021/np100625a

44. Scala, F.; Fattorusso, E.; Menna, M.; Taglialatela-Scafati, O.; Tierney, M.; Kaiser; Tasdemir, D. Mar. Drugs. 2010, 8, 2162.

https://doi.org/10.3390/md8072162

45. Yamada, Y., Takeuchi, S.; Yoneda, M.; Ito, S.; Sano, Y.; Nagasawa, K.; Matsuura, N.; Uchinaka, A.; Murohara, T.; Nagata, K. Int. J. Cardiol. 2017, 240, 332.

https://doi.org/10.1016/j.ijcard.2017.11.016

46. Koyama, M.; Ohtani, N.; Kai, F. J. Med. Chem. 1987, 30, 552.

https://doi.org/10.1021/jm00386a019

47. Artico, M.; Di SantoM R.; Costi, R. Bioorg. Med. Chem. Lett. 1997, 7, 1931.

https://doi.org/10.1016/S0960-894X(97)00340-5

48. Gokhan-Kelekci, N.; Yabanoglu, S.; Kupeli, E.; Salgın, U.; Ozgen, O.; Ucar, G.; Yesilada, E.; Kendi, E.; Yesilada, A.; Bilgin, A.A. Bioorg. Med. Chem. 2007, 15, 5775.

https://doi.org/10.1016/j.bmc.2007.06.004

49. Fukuda, T.; Ishibashi, F.; Iwao, M. Heterocycles 2011, 83, 491.

https://doi.org/10.3987/REV-10-686

50. Kumar, P.R.; Raju, S.P.; Goud, S.; Sailaja, M.; Sarma, M.R.; Reddy, G.O.; Kumar, M.P.; Reddy, V.K.; Suresh, T.; Hegde, P. Bioorg. Med. Chem. 2004, 12, 1221.

https://doi.org/10.1016/i.bmc.2003.11.003

51. Lee, H.; Lee, J.; Lee, S. Bioorg. Med. Chem. Lett. 2001, 11, 3069.

https://doi.org/10.1016/S0960-894X(01)00624-2

52. Narule, M.N.; Gaidhane, M.K.; Gaidhane, P.K. J. Pharm. Res. 2013, 6, 626.

https://doi.org/10.1016/j.jopr.2013.04.046

53. Meshram, H.M.; Prasad, B.R.V.; Kumar, D.A. Tetrahedron Lett. 2010, 51, 3477.

https://doi.org 10.1016/j.tetlet.2010.03.036

54. Ragno, R.; Simeoni, S.; Rotili, D.; Caroli, A.; Botta, G.; Brosch, G.; Massa, S.; Mai, A. Eur. J. Med. Chem. 2008, 43, 621.

https://doi.org/10.1016/j.ejmech.2007.05.004

55. Di Sanro, R.; Tafi, A.; Costi, R.; Artico, M.; Miele, G.; Lavecchia, A.; Novellino, E.; Bergamini, A.; Cancio, R.; Maga, G. Chem. Med. Chem. 2006, 1, 1367.

https://doi.org/0.1002/cmdc.200600119

56. Domling, A. Chem. Rev. 2006, 106, 17.

https://doi.org/10.1021/cr0505728

57. Sanchez-Duque, M.M.; Allais, C.; Isambert, N.; Constantieux, T.; Rodriguez, J. Top. Heterocycl. Chem. 2010, 23, 227.

https://doi.org/10.1007/7081 200923

58. Jiang, B.; Rajale, T.; Wever, W.; Tu, S.-J.; Li, G. Chem. Asian J. 2010, 5, 2318. 
https://doi.org 02/asia.201000310

59. Eckert, H. Molecules 2012, 17, 1074.

https://doi.org/10.3390/molecules17011074

60. Climent, M.J.; Corma, A.; Iborra, S. RSC Adv. 2012, 2, 16.

https://doi.org/10.1039/C1RA00807B

61. De Graaff, C.; Ruijter, E.; Orru, R.V.A. Chem. Soc. Rev. 2012, 41, 3969.

https://doi.org/10.1039/C2CS15361K

62. Van der Heijden, G.; Ruijter, E.; Orru, R.V.A. Synlett 2013, 24, 666.

https://doi.org/10.1055/s-0032-1318222

63. Ulaczyk-Lesanko, A.; Hall, D.G. Curr. Opin. Chem. Biol. 2005, 9, 266.

https://doi.org/10.1016/j.cbpa.2005.04.003

64. Touré, B.B.; Hall, D.G. Chem. Rev. 2009, 109, 4439.

https://doi.org/10.1021/cr800296p

65. Perreault, S.; Rovis, T. Chem. Soc. Rev. 2009, 38, 3149.

https://doi.org/10.1039/B816702H

66. Rotstein, B.H.; Zaretsky, S.; Rai, V.; Yudin, A.K. Chem. Rev. 2014, 114, 8323.

https://doi.org/10.1021/cr400615v

67. Hulme, C.; Gore, V. Curr. Med. Chem. 2003, 10, 51.

https://doi.org/10.2174/0929867033368600

68. Biggs-Houck, J.E., Younai, A.; Shaw, J.T. Curr. Opin. Chem. Biol. 2010, 14, 371.

https://doi.org/10.1016/j.cbpa.2010.03.003

69. Domling, A. Wang, W.; Wang, K. Chem. Rev. 2012, 112, 3083.

https://doi.org/10.1021/cr100233r

70. R. Javahershenas, J. Khalafy, J. Chem. Rev. 2019, 1, 233.

http://dx.doi.org/10.33945/SAMI/JCR.2019.3.4

71. Eftekhari-Sis, B.; Zirak, M.; Movasaghpour Akbari A.A. Chem. Rev. 2013, 113, 2958. https://doi.org/10.1021/cr300176g

72. Ma, Zh.; Ma, Z.; Zhang, D. Molecules 2018, 23, 2666.

https://doi.org/10.3390/molecules23102666

73. Khajuria, R.; Dham, S.; Kapoor, K.K. RSC Adv., 2016, 6, 37039.

https://doi.org/10.1039/C6RA03411J

74. Anaraki-Ardakani, H.; Noei, M.; Karbalaie-Harofteh, M.; Zomordbakhsh, S. Eur. J. Chem. 2012, 9, 2239.

https://doi.org/10.1155/2012/915861

75. Musawwer Khan, M.; Khan, S.; Saigal; Singh, A. Tetrahedron Lett. 2019, 60, 150996.

https://doi.org/10.1016/i.tetlet.2019.150996

76. Wang, H.; Liu, X.; Feng, X.; Shi, D. Green Chem. 2013, 15, 3307.

https://doi.org/10.1039/C3GC41799A

77. Mehrabi, H.; Alizadeh-Bami, F.; Ranjbar-Karimi, R. J. Iran. Chem. Soc. 2018, 5, 1961. https://doi.org/10.1007/s13738-018-1393-0

78. Feng, X.; Wang, Q.; Lin, W.; Dou, G.-L.; Huang, Zh.-B.; Shi, D.-Q. Org. Let. 2013, 15, 2542. https://doi.org/10.1021/ol4010382

79. Dhinakaran, I.; Vediappen, P.; Bhuvanesh, N. ACS Comb. Sci. 2016, 18, 236.

https://doi.org/10.1021/acscombsci.5b00154 
80. Ambethkar, S.; Padmini, V.; Bhuvanesh, N. New J. Chem. 2016, 40, 4705.

https://doi.org/10.1039/C5NJ03444B

81. Eftekhari-Sis, B.; Akbar, A.; Amirabedi, M. Chem. Heterocycl. Comp. 2011, 46, 1330.

https://doi.org/10.1007/s10593-011-0669-4

82. Bhat, S.I.; Darshak Trivedi, R. Tetrahedron Lett. 2013, 54, 5577.

https://doi.org/10.1016/j.tetlet.2013.07.153

83. Mousavizadeh, F.; Talebizadeh, M.; Anary-Abbasinejad, M. Tetrahedron Lett. 2018, 59, 2970. https://doi.org/10.1016/i.tetlet.2018.06.043

84. Anary-Abbasinejad, M.; Nezhad-Shshrokhabadi, F.; Mohammadi, M. Mol Divers. $2019,1$. https://doi.org/10.1007/s11030-019-09984-x

85. Karamthulla, S.; Pal, S.; Khan, M.N.; Choudhury, L.H. Synlett 2014, 25, 1926.

https://doi.org/10.1055/s-0034-1378329

86. Dommaraju, Y.J.; Prajapati, D. Mol. Divers. 2015, 19, 173.

https://doi.org/10.1007/s11030-014-9547-1

87. Chen, Z.; Yang, X.; Su, W. Synlett 2017, 28, 1463.

https://doi.org/10.1055/s-0036-1588168

88. Liu, C.; Zhou, L.; Jiang, D.; Gu, Y. Asian J. Org. Chem. 2016, 5, 367.

https://doi.org/10.1002/ajoc.201500497

89. Kolos, N.N.; Zubar, V.V.; Omelchenko, I.V.; Musatov, V.I. Chem. Heterocycl. Comp. 2016, $52,237$. https://doi.org/10.1007/s10593-016-1869-8

90. Liu, J.-Y; Li, Q.-Y.; Jiang; B.; Tu, S.-J. RSC Advan. 2013, 3, 5056.

https://doi.org/10.1039/c3ra40252e

91. Masoudi, M.; Anary-Abbasinejad, M. Tetrahedron Lett. 2016, 57, 103.

https://doi.org/10.1016/i.tetlet.2015.11.075

92. Jalani, H.B.; Lee, K.; Mali, J.R.; Choi, Y.; Park, H.; Lee, J.K.; Lee, K. Adv. Synth. Catal. 2018, $360,4073$. https://doi.org/10.1002/adsc.201800492

93. Bayat, M.; Nasri, S.; Notash, B. Tetrahedron 2017, 73, 1522.

https://doi.org/10.1016/i.tet.2017.02.005

94. Maity, S.; Pathak, S.; Pramanik, A. Eur. J. Org. Chem. 2014, 21, 4651.

htps://doi.org/10.1002/ejoc.201402085

95. Wang, H.-Y.; Shi, D.-Q. ACS Comb. Sci. 2013, 15, 261.

https://doi.org/10.1021/co3001428

96. Wang, S.S; Zhu, Q.W.; Liu, S. Res. Chem. Intermed. 2015, 41, 2879.

https://doi.org/10.1007/s11164-013-1396-5

97. Jiang, B.; Li, Y.; Tu, M.-S.; Wang, S.-L.; Tu, S.-J.; Li, G. J. Org. Chem. 2012, 77, 7497.

https://doi.org/10.1021/jo301323r

98. Li, Y.; Li, Q.-Y.; Xu, H.-W.; Fan, W.; Jiang, B.; Wang, S.-L.; Tu, S.-J. Tetrahedron 2013, 69, 2941. https://doi.org/10.1016/i.tet.2013.02.026

99. Tu, X.-C.; Fan, W.; Jiang, B.; Wang, S.-L.; Tu, S.-J. Tetrahedron 2013, 69, 6100. https://doi.org/10.1016/i.tet.2013.05.063

100. Fu, L.-P., Shi, Q.-Q., Shi, Y.; Jiang, B.; Tu, S.-J. ACS Comb. Sci. 2013, 15, 135. https://doi.org/10.1021/co3001428

101. Reddy, M.N.; Kumar, P.P. Tetrahedron Lett. 2017, 58, 4790. https://doi.org/10.1016/i.tetlet.2017.11.027 
102. Maity, S.; Pramanik, A. Synthesis 2013, 45, 2853.

https://doi.org/10.1055/s-0033-1339651

103. Maity, S.; Pathak, S.; Pramanik, A. Eur. J. Org. Chem., 2013, 2479.

https://doi.org/10.1002/ejoc.201402085

104. Lin, W.; Zheng, Y.-X.; Xun, Z.; Huang, Z.-B.; Shi, D.-Q. ACS Comb. Sci. 2017, 19, 708. https://doi.org/10.1021/acscombsci.7b00126

105. Naidu, P. S.; Kolita, S.; Sharma, M.; Bhuyan, P. J. J. Org. Chem. 2015, 80, 6381. https://doi.org/10.1021/acs.joc.5b00533

106. Jiang, B.; Li, Q.-Y.; Zhang, H.; Tu, S.-J.; Pindi, S.; Li, G. Org. Lett. 2012, 14, 700. https://doi.org/10.1021/ol203166c

107. Yang, X.; Chen, Z.; Zhong, W. Eur. J. Org. Chem. 2017, 2258. https://doi.org/10.1002/ejoc.201700054

108. Yang, X.; Zheng, L.; Chen, Z.; Zhong, W. Syn. Comm. 2018, 48, 929 https://doi.org/10.1080/00397911.2018.1430237

109. Chen, Z.; Yang, X.; Su, W. Tetrahedron Lett. 2015, 56, 2476. https://doi.org/10.1016/i.tetlet.2015.03.095

110. Javahershenas, R.; Khalafy, J. Heterocycl. Commun. 2018, 24, 37. https://doi.org/10.1515/hc-2017-0187

111. Javahershenas, R.; Khalafy, J. J. Mex. Chem. Soc. 2018, 61. https://doi.org/10.29356/imcs.v62i1.340

112. Chen, X.-B.; Liu, Z.-C.; Yang, L.-F.; Yan, S.-J.; Lin, J. ACS Sustainable Chem. Eng. 2014, 2, 1155. https://doi.org/10.1021/sc500170d

113. Chen, X.-B.; Yan, S.-J.; Su, A.; Liu, W.; Lin, J. Tetrahedron 2015, 71, 4745. https://doi.org/10.1016/i.tet.2015.05.067

114. Chen, X.-B.; Wang, X.-Y.; Zhu, D.-D.; Yan, S.-J.; Lin, J. Tetrahedron 2014, 70, 1047. https://doi.org/10.1016/i.tet.2013.12.062

115. Jiang, B.; Li, Y.; Tu, M.-S.; Wang, S.-L.; Tu, S.-J.; Li, G. J. Org. Chem. 2014, 79, 5258. https://doi.org/10.1021/j0500823z

\section{Authors' Biographies}

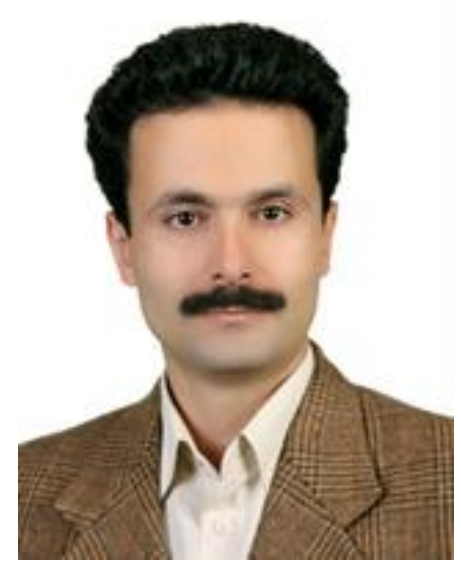

Ramin Javahershenas was born in Urmia, Iran in 1971. He received his B.Sc. degree in Applied Chemistry from 
Tabriz University, Tabriz, Iran, in 1993, his M.Sc. degree in Organic Chemistry from the Urmia University, Urmia, Iran, under the supervision of Professor Naser Ardabilchi in 1999 and his Ph.D. degree in Organic chemistry from Urmia University, Urmia, Iran under the supervision of Professor Jabbar Khalafy, in 2017. His research interests include organic synthesis, heterocyclic synthesis, asymmetric synthesis, natural products synthesis, synthetic methodology and applications of various catalysts in multicomponent reactions.

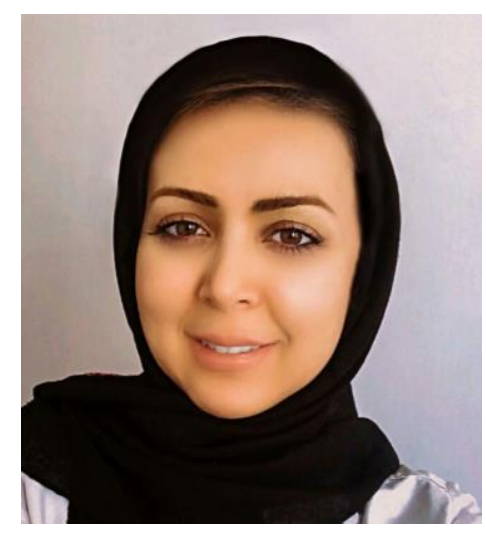

Fatemeh Majidi Arlan was born in Urmia, Iran in 1984. She received her B.Sc. degree in pure Chemistry from Urmia University, Urmia, Iran, in 2007, her M.Sc. degree in analytical Chemistry from the Urmia University, Urmia, Iran, under the supervision of Professor Khalil Farhadi in 2010 and her Ph.D. degree in Organic chemistry from Urmia University, Urmia, Iran under the supervision of Professor Jabbar Khalafy, in 2018. Currently she is working as a researcher on Research Department of Chemistry, Iranian Academic Center for Education, Culture and Research.

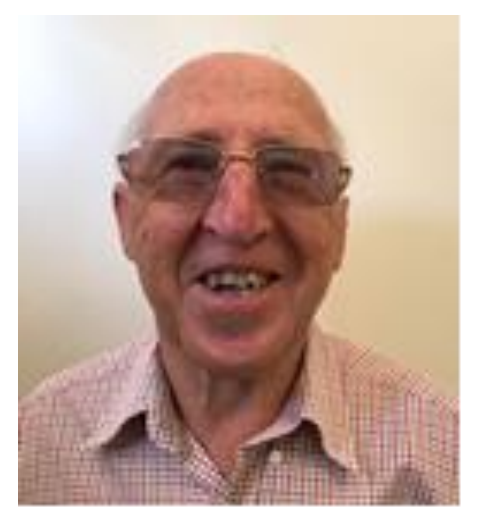

Rolf Herman Prager was born in Australia in 1937, and is a graduate of the University of Sydney and Imperial College, London. He is now Emeritus Professor in Chemistry at Flinders University, Adelaide. He has published widely in the fields of natural products, structure determination and synthesis, and in medicinal chemistry, particularly associated with pain relief. 


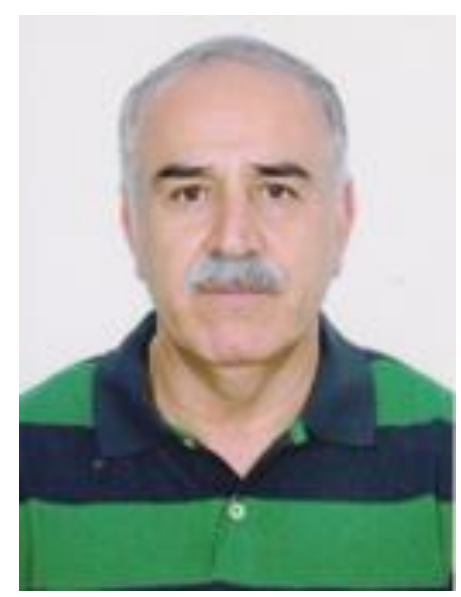

Jabbar Khalafy was born in Marand, Iran in 1952. He received his B.Sc. degree in Chemistry from Tabriz University, Tabriz, Iran, in 1975, his M.Sc. degree in Organic Chemistry from Manchester University, Manchester, England, in 1977 and his Ph.D. degree in Organic Chemistry from Manchester University, Manchester, England under the supervision of Professor J.M. Bruce, in 1979. He is Full Professor in the faculty of Chemistry at Urmia University, Urmia, Iran. His research interests include organic synthesis, heterocyclic synthesis, asymmetric synthesis, natural products synthesis, FVP, synthetic methodology and applications of various catalysts in multicomponent reactions. 